Nevada

DOE/NV/11718--260

Environmental

Restoration

Project

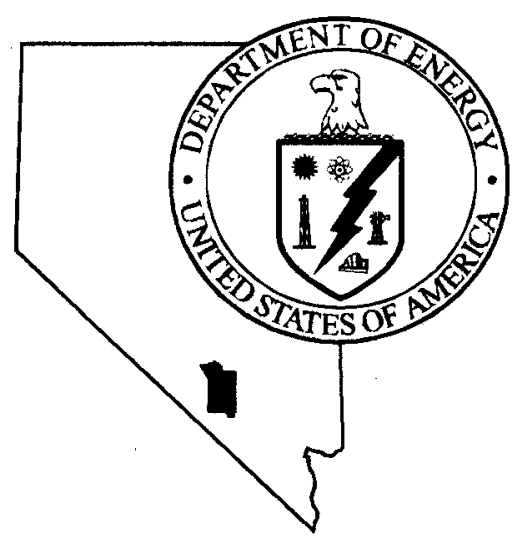

Streamlined Approach for

Environmental Restoration

Closure Report for

Corrective Action Unit 126

Area 25 Aboveground

Storage Tanks

Nevada Test Site, Nevada

Controlled Copy No.:

Revision: 0

December 1998
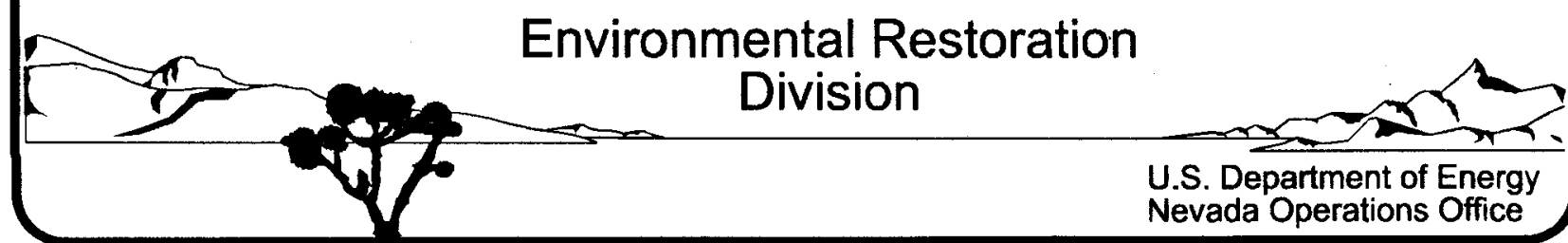
Available to the public from:

\author{
U.S. Department of Commerce \\ National Technical Information Service \\ 5285 Port Royal Road \\ Springfield, VA 22161 \\ (703) $487-4650$
}

Available electronically at http://www.doe.gov/bridge. Available to U.S. Department of Energy and its contractors in paper from:

U.S. Department of Energy

Office of Scientific and Technical Information

P.O. Box 62

Oak Ridge, TN 37831-0062

(423) 576-8401

Reference herein to any specific commercial product, process, or service by trade name, trademark, manufacturer, or otherwise, does not necessarily constitute or imply its endorsement, recommendation, or favoring by the U.S. Government or any agency thereof or its contractors or subcontractors. 


\section{STREAMLINED APPROACH FOR ENVIRONMENTAL RESTORATION CLOSURE REPORT FOR \\ CORRECTIVE ACTION UNIT 126 \\ AREA 25 ABOVEGROUND STORAGE TANKS \\ NEVADA TEST SITE, NEVADA}

\section{Controlled Copy No.:}

Revision: 0

December 1998

Prepared for the U.S. Department of Energy

Nevada Operations Office

Work Performed Under Contract No. DE-AC08-96NV11718 
THIS PAGE INTENTIONALLY LEFT BLANK 


\section{STREAMLINED APPROACH FOR ENVIRONMENTAL RESTORATION CLOSURE REPORT FOR CORRECTIVE ACTION UNIT 126 AREA 25 ABOVEGROUND STORAGE TANKS NEVADA TEST SITE, NEVADA}

Approved by: Janet S. Spezeln.Whe Janet L. Appenzeller-Wing, Project Manager Industrial Sites Project

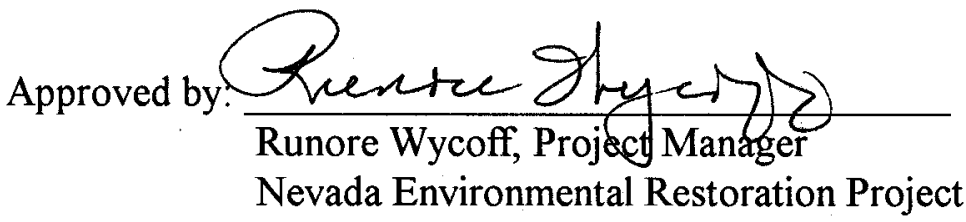

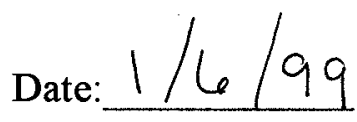

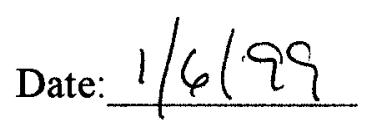


THIS PAGE INTENTIONALLY LEFT BLANK 


\section{TABLE OF CONTENTS}

ACRONYMS AND ABBREVIATIONS $\ldots \ldots \ldots \ldots \ldots \ldots \ldots \ldots \ldots$ vii

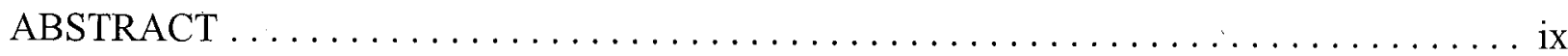

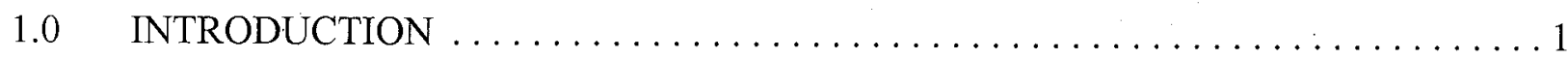

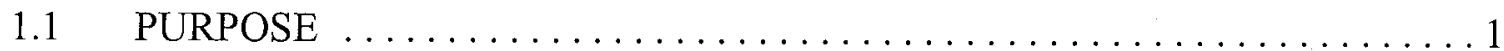

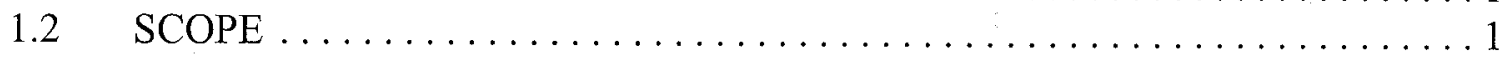

1.3 CLOSURE REPORT CONTENTS $\ldots \ldots \ldots \ldots \ldots \ldots \ldots \ldots \ldots \ldots \ldots \ldots \ldots \ldots$

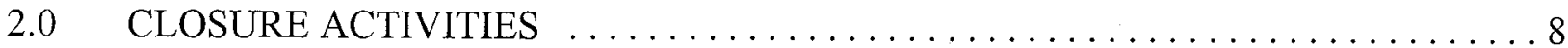

2.1 DESCRIPTION OF CORRECTIVE ACTION ACTIVITIES $\ldots \ldots \ldots \ldots \ldots 8$

2.1.1 CAS 25-01-01: Sulfuric Acid and Sodium Hydroxide Tanks . . . . . . 8

2.1.1.1 Sulfuric Acid Tank, T-2003 .................. 8

2.1.1.2 Sodium Hydroxide Tank, T-2002 . . . . . . . . . . . 13

2.1.2 CAS 25-01-02: Diesel Fuel Tank, T-2001 ............... 13

2.1.3 CAS 25-01-03: Diesel Fuel Tank, T-2401 ................. 14

2.1.4 CAS 25-01-04: Charcoal Adsorption Furnace Tank, D-2001 . . . . . . . 14

2.1.5 CAS 25-01-08: Nalcool Tank ....................... 19

2.2 DEVIATIONS FROM THE APPROVED SAFER WORK PLAN $\ldots \ldots \ldots 19$

2.3 CORRECTIVE ACTION SCHEDULE AS COMPLETED . . . . . . . . . . . . 19

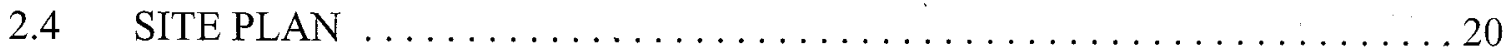

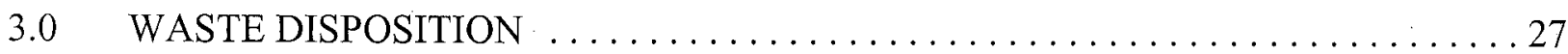

3.1 ASBESTOS-CONTAINING MATERIAL $\ldots \ldots \ldots \ldots \ldots \ldots \ldots \ldots \ldots 27$

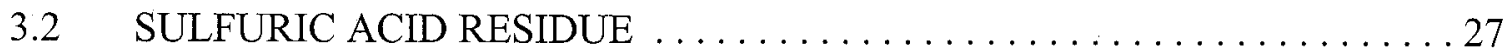

3.3 PETROLEUM HYDROCARBON-IMPACTED SOIL $\ldots \ldots \ldots \ldots \ldots \ldots 27$

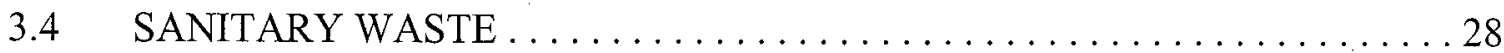

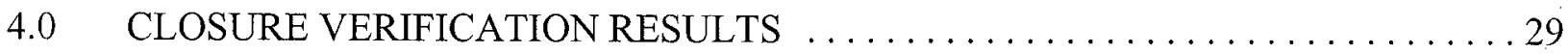

4.1 CAS 25-01-01: SULFURIC ACID AND SODIUM HYDROXIDE TANKS . . 29

4.2 CAS 25-01-02: DIESEL FUEL TANK . . . . . . . . . . . . . . . . . 29

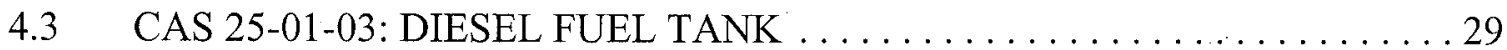

4.4 CAS 25-01-04: CHARCOAL ADSORPTION FURNACE TANK $\ldots \ldots \ldots 30$

4.5 CAS 25-01-08: NALCOOL TANK ....................... 30

5.0 CONCLUSIONS AND RECOMMENDATIONS $\ldots \ldots \ldots \ldots \ldots \ldots \ldots \ldots \ldots \ldots$

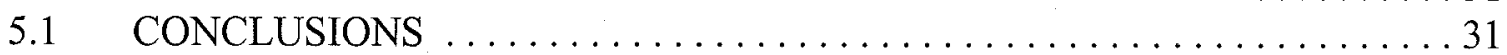

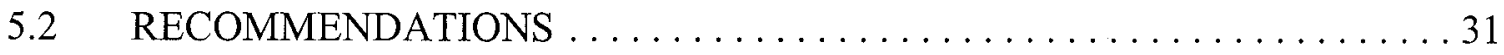

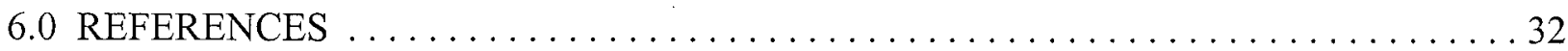




\section{TABLE OF CONTENTS (continued)}

APPENDIX A - SPILL NOTIFICATION REPORTS

APPENDIX B- LABORATORY ANALYTICAL DATA

APPENDIX C- WASTE DISPOSAL DOCUMENTS

DISTRIBUTION LIST

\section{FIGURES}

FIGURE 1 - CAU 126: SITE LOCATION MAP $\ldots \ldots \ldots \ldots \ldots \ldots \ldots \ldots \ldots \ldots \ldots \ldots \ldots \ldots$

FIGURE 2 - ENGINE TEST STAND: FORMER TANK LOCATIONS $\ldots \ldots \ldots \ldots \ldots \ldots$.

FIGURE 3 - CAS 25-01-01: SULFURIC ACID AND SODIUM HYDROXIDE TANKS . . . . 9

FIGURE 4 - CAS 25-01-02: DIESEL FUEL TANK $\ldots \ldots \ldots \ldots \ldots \ldots \ldots \ldots \ldots \ldots$

FIGURE 5 - CAS 25-01-03: DIESEL FUEL TANK $\ldots \ldots \ldots \ldots \ldots \ldots \ldots \ldots \ldots \ldots \ldots \ldots \ldots$

FIGURE 6 - CAS 25-01-04: CHARCOAL ADSORPTION FURNACE TANK . . . . . . . 21

FIGURE 7 - CAS 25-01-08: NALCOOL TANK $\ldots \ldots \ldots \ldots \ldots \ldots \ldots \ldots \ldots \ldots \ldots \ldots \ldots \ldots$

\section{TABLES}

TABLE 1 - SUMMARY OF ANALYTICAL RESULTS $\ldots \ldots \ldots \ldots \ldots \ldots \ldots \ldots \ldots$

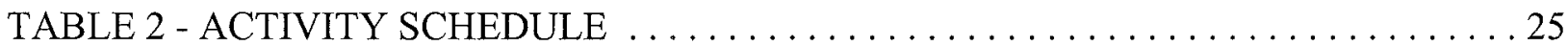


ACM asbestos-containing material

bgs below ground surface

BN Bechtel Nevada

CAS Corrective Action Site

CAU Corrective Action Unit

CFR Code of Federal Regulations

CSA Central Support Area

$\mathrm{cm} \quad$ centimeter(s)

CR Closure Report

DOE/NV U.S. Department of Energy, Nevada Operations Office

DOT U.S. Department of Transportation

EPA U.S. Environmental Protection Agency

ETS Engine Test Stand

FFACO Federal Facility Agreement and Consent Order

$\mathrm{ft} \quad$ feet

gal gallon(s)

in inch(es)

IT IT Corporation

$\mathrm{kg} \quad$ kilogram(s) 


\section{ACRONYMS AND ABBREVIATIONS (continued)}

L

lbs

$\mathrm{m}$

$\mathrm{m}^{3}$

$\mathrm{mg} / \mathrm{kg}$

$\mathrm{mg} / \mathrm{L}$

NDEM

NDEP

NTS

ppm

RCRA

REECo

RQ

SAFER

TCLP

TPH

$\mathrm{yd}^{3}$ liter(s)

pounds

meter(s)

cubic meter(s)

milligram(s) per kilogram

milligram(s) per liter

Nevada Division of Emergency Management

Nevada Division of Environmental Protection

Nevada Test Site

parts per million

Resource Conservation and Recovery Act

Reynolds Electrical \& Engineering Company, Inc.

Reportable Quantity

Streamlined Approach for Environmental Restoration

toxicity characteristic leaching procedure

total petroleum hydrocarbon

cubic yards 


\section{ABSTRACT}

This report addresses the closure of Corrective Action Unit (CAU) 126, the Area 25 Aboveground Storage Tanks located at the Engine Test Stand facility, and the Central Support Area, Nevada Test Site, Neviada. This unit is listed in the Federal Facility Agreement and Consent Order and is subdivided into five Corrective Action Sites. Closure was completed at all five sites following the Nevada Division of Environmental Protection approved Streamlined Approach for Environmental Restoration Work Plan for Corrective Action Unit 126: Closure of Aboveground Storage Tanks, Nevada Test Site, Nevada.

The sites consisted of aboveground storage tanks, two of which were used to store diesel fuel and one stored Nalcool (an antifreeze mixture). The remaining tanks were used as part of a water demineralization process and stored either sulfuric acid or sodium hydroxide, and one was used as a charcoal adsorption furnace. Closure was completed by removing the asbestos-containing material, containerizing the sulfuric acid residue, removing the tanks and associated piping and supports, excavating impacted soil, and disposing of the accumulated waste.

Based upon site observations and the soil sample analytical results, it is requested that a Notice of Completion be provided by the Nevada Division of Environmental Protection for CAU 126. Upon closure approval the unit will be promoted from Appendix III of the Federal Facilities Agreement and Consent Order to Appendix IV, "Closed Corrective Action Units." 
THIS PAGE INTENTIONALLY LEFT BLANK 


\subsection{INTRODUCTION}

This report addresses the closure of several aboveground storage tanks located in Area 25 of the Nevada Test Site (NTS). The unit is identified as Corrective Action Unit (CAU) 126 in the Federal Facility Agreement and Consent Order (FFACO) and is listed as having five Corrective Action Sites (CASs). This plan addresses the Streamlined Approach for Environmental Restoration (SAFER) closure for the sites.

Four of the CASs are located at the Engine Test Stand (ETS) complex and one is located in the Central Support Area (CSA) (Figure 1). The ETS CAS consists of aboveground tanks, two of which were used to store diesel fuel (CAS 25-01-02 and 25-01-03) and one stored Nalcool (CAS 25-01-08), an antifreeze mixture. The remaining tanks were used as part of a water demineralization process done in Building 3320. One of these sites, CAS 25-01-01, consisted of two tanks: one stored sulfuric acid and the other sodium hydroxide. The tank associated with CAS 25-01-04 was used as a charcoal adsorption furnace. The former locations of the ETS tanks is shown on Figure 2. CAS 25-01-08 no longer exists at the identified location in the CSA and will be closed with no further action.

\section{$1.1 \quad$ PURPOSE}

The purpose of this Closure Report (CR) is to provide documentation of the corrective action activities and provide data confirming the corrective action. The closure methodology was based on information provided in the preliminary assessment reports (IT Corporation [IT], 1997a, 1997b, 1997c, 1997d, 1998). The work was completed as outlined in the Streamlined Approach for Environmental Restoration Work Plan for Corrective Action Unit 126: Closure of Aboveground Storage Tanks, Nevada Test Site, Nevada (Department of Energy, Nevada Operation Office [DOE/NV], 1998b). The documentation provided in this report supports a request to the Nevada Division of Environmental Protection (NDEP) for closure of CAU 126.

\subsection{SCOPE}

Closure was accomplished by completing the following activities:

- Removing the asbestos-containing material (ACM) on the piping associated with CAS 25-01-01 and 25-01-04.

- Containerizing the sulfuric acid residue associated with CAS 25-01-01.

- Dismantling the tanks, disconnecting the piping, and demolishing the support structures, where applicable. 
- Excavating impacted soils.

- Collecting samples for waste characterization and site evaluation purposes.

- Disposing of all waste.

- Documenting all activities.

\subsection{CLOSURE REPORT CONTENTS}

This CR has been developed to support the closure of CASs 25-01-01, 25-01-02, 25-01-03, 25-01-04, and 25-01-08. The format of the report is as follows:

- Section 1.0 - Introduction, Purpose, and Scope.

- Section 2.0 - Closure Activities.

- Section 3.0 - Waste Disposition.

- Section 4.0 - Closure Verification Results.

- Section 5.0 - Conclusions and Recommendations.

- Section 6.0 - References.

- Appendix A - Spill Notification Reports.

- Appendix B - Laboratory Analytical Data.

- Appendix C - Waste Disposal Documents.

The SAFER Plan was implemented using information and guidance provided from the following documents:

- Streamlined Approach for Environmental Restoration Work Plan for Corrective Action Unit 126: Closure of Aboveground Storage Tanks, Nevada Test Site, Nevada (DOE/NV, 1998b).

- Site-Specific Health and Safety Plan for SAFER Closure Area 25 Aboveground Storage Tanks, Engine Test Stand, Nevada Test Site (BN, 1998a). 


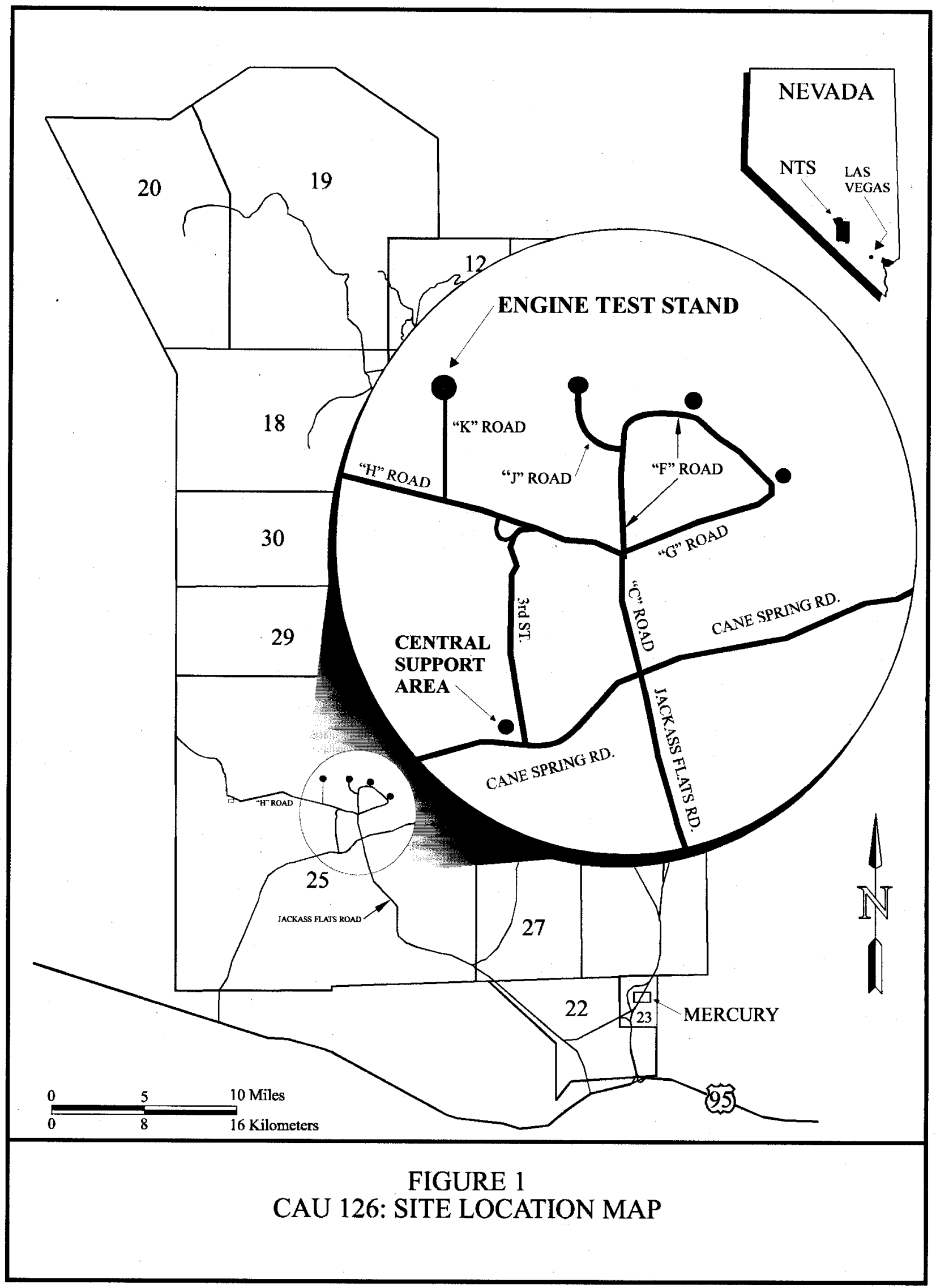


THIS PAGE INTENTIONALLY LEFT BLANK 


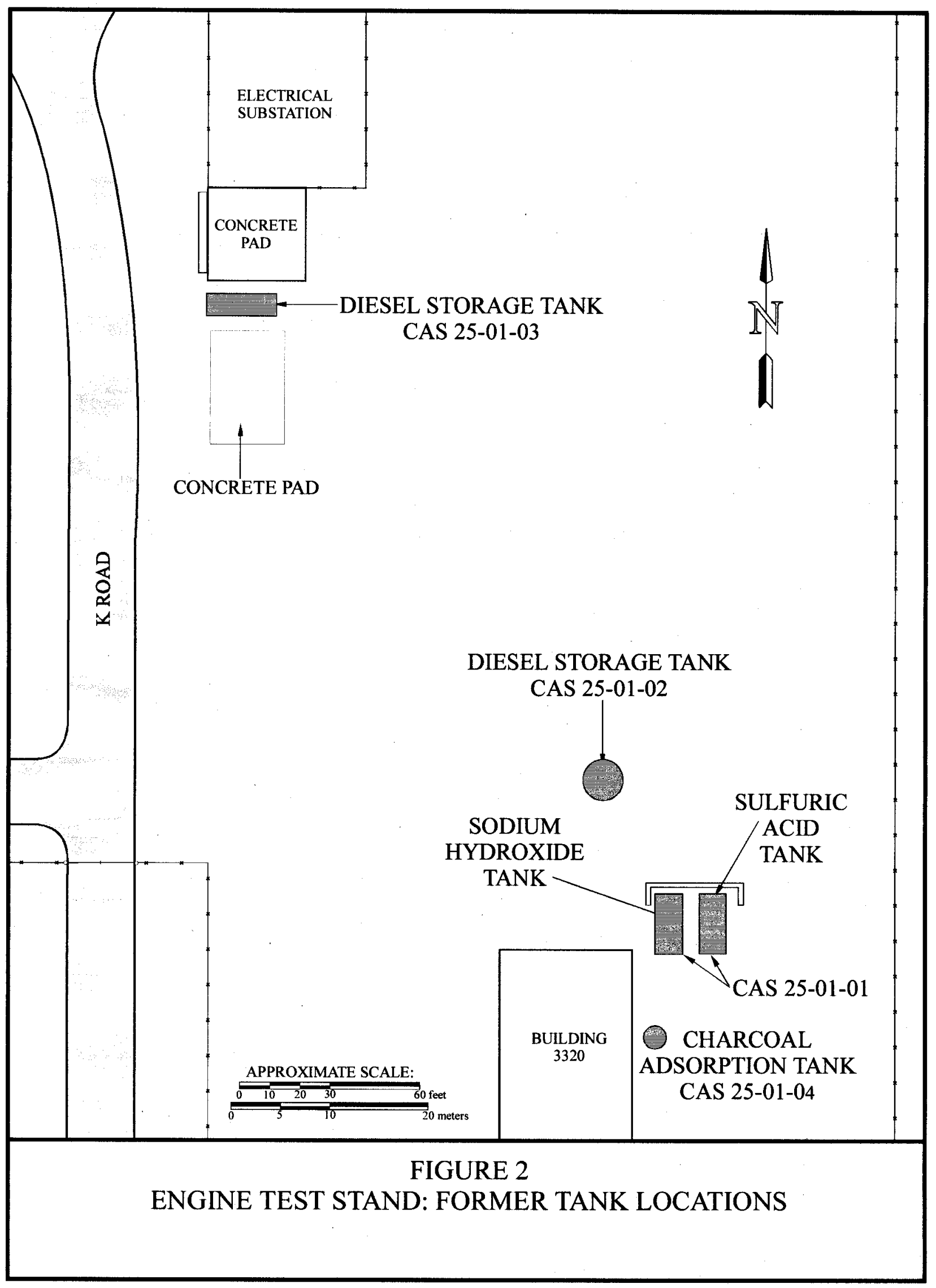


THIS PAGE INTENTIONALLY LEFT BLANK 
- Field Management Plan for Corrective Action Unit No. 126 SAFER Closure of Area 25 Aboveground Storage Tanks, Nevada Test Site, Nevada (BN, 1998b).

- Nevada Environmental Restoration Project, Project Management Plan (DOE/NV, 1994).

- Nevada Environmental Restoration Project, Health and Safety Plan (DOE/NV, 1998a).

- Nevada Environmental Restoration Project, Industrial Sites, Quality Assurance Project Plan, Nevada Test Site (DOE/NV, 1996a).

- Preliminary Assessment for CAU No. 126: Area 25 Aboveground Storage Tanks, CAS No. 25-01-01: Aboveground Storage Tanks (2) Nevada Test Site, Nevada (IT, 1997a).

- Preliminary Assessment for CAU No. 126: Area 25 Aboveground Storage Tanks, CAS No. 25-01-02: Aboveground Storage Tank, Nevada Test Site, Nevada (IT, 1998).

- Preliminary Assessment for CAU No. 126: Area 25 Aboveground Storage Tanks, CAS No. 25-01-03: Aboveground Storage Tank, Nevada Test Site, Nevada (IT, 1997b).

- Preliminary Assessment for CAU No. 126: Area 25 Aboveground Storage Tanks, CASNo. 25-01-04: Aboveground Storage Tank, Nevada Test Site, Nevada (IT 1997c).

- Preliminary Assessment for CAUNo. 126: Area 25 Aboveground Storage Tanks, CAS No. 25-01-08: Aboveground Storage Tank, Nevada Test Site, Nevada (IT, 1997d). 


\subsection{CLOSURE ACTIVITIES}

\subsection{DESCRIPTION OF CORRECTIVE ACTION ACTIVITIES}

\subsubsection{CAS 25-01-01: Sulfuric Acid and Sodium Hydroxide Tanks}

CAS 25-01-01 consisted of two 19,000-liter (L) (5,000-gallon [gal]) tanks located at the northeast corner of Building 3320. One tank, T-2002, was used to store sodium hydroxide and the other, tank T-2003, was used for sulfuric acid storage. The contents of the tanks were used in the demineralization process done in Building 3320. Cleanup at this CAS started on August 5, 1998, and was completed on August 12, 1998. All waste associated with this CAS was disposed of by August 17, 1998. Figure 3 contains "before" and "after" photographs of the site.

\subsubsection{Sulfuric Acid Tank, T-2003}

The primary constituent of concern (COC) for the closure of CAU 126, was the acid residue because of the potential for worker exposure. The acid tank was severely corroded and about 0.3 meter $(\mathrm{m})$ ( 1 foot [ft]) of powdery residue was present in the bottom of the tank. Some residue was also present on the ground below the tank. The substance did not exhibit the characteristic of corrosivity as defined by the Resource Conservation and Recovery Act (RCRA) because it was a solid (40 Code of Federal Regulations [CFR] Part 261). However, the containers were compatible with the waste, per Department of Transportation [DOT] requirements, i.e., lined, steel drums.

A sample of the sulfuric acid residue was collected on June 15, 1998, and submitted for laboratory analysis for RCRA-regulated metals using U.S. Environmental Protection Agency (EPA) Toxicity Characteristic Leaching Procedure (TCLP) Method 6010 (EPA, 1996). The concern was that the acid reacting with the steel tank may have caused the concentration of chromium to be elevated above the regulatory action level of five milligrams per liter $(\mathrm{mg} / \mathrm{L})$ (40 CFR Part 261). The concentration of chromium in the sample was $2.2 \mathrm{mg} / \mathrm{L}$, therefore the material was not handled as a hazardous waste. A summary of the analytical data is presented in Table 1 and copies of the laboratory data has been included in Appendix A.

The sulfuric acid residue was placed in 208-L (55-gal) lined, steel drums. The cleanup began on August 10, 1998, and was completed on August 12, 1998. A total of ten drums were filled. The crushed sulfuric acid tank was transported to the Area 9 10c Sanitarty Landfill on August 11, 1998. The drums were transported there on August 17, 1998.

During the cleanup of the residue and disassembly of the support structure, a pipe was inadvertently opened at a flange at the bottom of the adjacent sodium hydroxide tank. Approximately $380 \mathrm{~L}$ (100 gal) of liquid were released to the concrete slab below and surrounding soil. During the removal of the soil impacted by this release, it was noted that the 


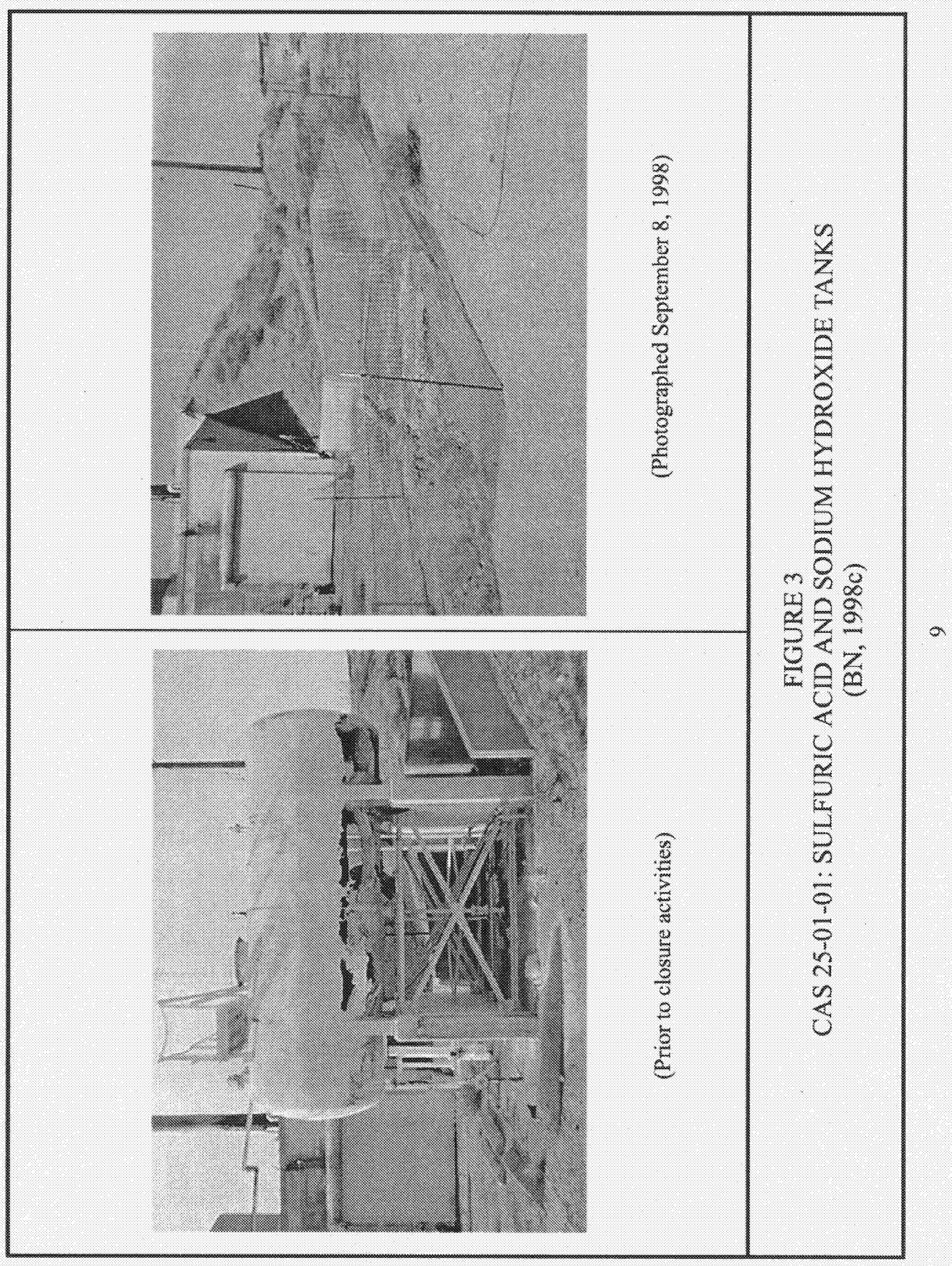


THIS PAGE INTENTIONALLY LEFT BLANK 
TABLE 1 - SUMMARY OF ANALYTICAL RESULTS

\begin{tabular}{|c|c|c|c|c|c|}
\hline $\begin{array}{l}\text { SAMPLE } \\
\text { NUMBER } \\
\end{array}$ & $\begin{array}{l}\text { SAMPLE DESCRIPTION/ } \\
\text { LOCATION }\end{array}$ & $\begin{array}{c}\text { RELATED } \\
\text { CAS }\end{array}$ & $\begin{array}{c}\text { DATE } \\
\text { COLLECTED }\end{array}$ & PARAMETER & RESULT \\
\hline 250103/SOUTH & $\begin{array}{c}\text { Preliminary surface soil sample, } \\
\text { tank T-2401 }\end{array}$ & $25-01-03$ & May 11,1998 & Unknown hydrocarbon* & $410 \mathrm{mg} / \mathrm{kg}$ \\
\hline 250103/WEST & $\begin{array}{c}\text { Preliminary surface soil sample, } \\
\text { tank T-2401 }\end{array}$ & $25-01-03$ & May 11, 1998 & Unknown hydrocarbon* & $850 \mathrm{mg} / \mathrm{kg}$ \\
\hline 250103/CENTER & $\begin{array}{l}\text { Preliminary surface soil sample, } \\
\text { tank T-2401 }\end{array}$ & $25-01-03$ & May 11,1998 & Unknown hydrocarbon* & $920 \mathrm{mg} / \mathrm{kg}$ \\
\hline $\mathrm{T}-2003$ & $\begin{array}{c}\text { Preliminary sulfuric acid residue } \\
\text { sample, tank T-2003 }\end{array}$ & $25-01-01$ & June 15. 1998 & TCLP Metals & $2.2 \mathrm{mg} / 1$ \\
\hline T-2001-VALVE & $\begin{array}{l}\text { Soil near drain valve, } \\
\text { about } 0.6 \mathrm{~m}(2 \mathrm{ft}) \mathrm{bgs}\end{array}$ & $25-01-02$ & August 4, 1998 & $\mathrm{TPH}$ in diesel/oil range & $2,500 \mathrm{mg} / \mathrm{kg}$ \\
\hline $\mathrm{T}-2001-0$ & $\begin{array}{l}\text { Soil beneath center of tank } \\
\text { T-2001 at ground surface }\end{array}$ & $25-01-02$ & August 4, 1998 & TPH in diesel/oil range & $340 \mathrm{mg} / \mathrm{kg}$ \\
\hline $\mathrm{T}-2001-2$ & $\begin{array}{l}\text { Soil beneath center of tank } \\
\text { T-2001 at approximately } 0.6 \mathrm{~m} \\
(2 \mathrm{ft}) \text { below sample } \mathrm{T}-2001-0\end{array}$ & $25-01-02$ & August 4, 1998 & $\mathrm{TPH}$ in diesel/oil range & $11,000 \mathrm{mg} / \mathrm{kg}$ \\
\hline $\mathrm{T}-2401-3 \mathrm{~S}$ & 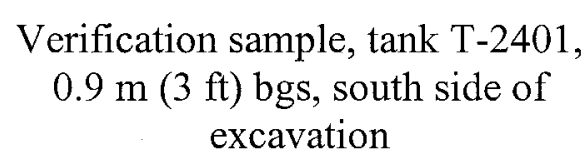 & $25-01-03$ & August 17, 1998 & $\mathrm{TPH}$ & $<20 \mathrm{mg} / \mathrm{kg}$ \\
\hline
\end{tabular}


TABLE 1 - SUMMARY OF ANALYTICAL RESULTS (Continued)

\begin{tabular}{||c|c|c|c|c|c||}
\hline $\begin{array}{c}\text { SAMPLE } \\
\text { NUMBER }\end{array}$ & $\begin{array}{c}\text { SAMPLE DESCRIPTION/ } \\
\text { LOCATION }\end{array}$ & $\begin{array}{c}\text { RELATED } \\
\text { CAS }\end{array}$ & $\begin{array}{c}\text { DATE } \\
\text { COLLECTED }\end{array}$ & PARAMETER & RESULT \\
\hline \hline T-2401-3N & $\begin{array}{c}\text { Verification sample, tank T-2401, } \\
0.9 \text { m (3 ft) bgs, north side of } \\
\text { excavation }\end{array}$ & $25-01-03$ & August 17,1998 & $<20 \mathrm{mg} / \mathrm{kg}$ \\
\hline T-2401-3PIPE & $\begin{array}{c}\text { Verification sample, tank T-2401, } \\
0.9 \text { m (3 ft) bgs, in pipeline } \\
\text { excavation }\end{array}$ & $25-01-03$ & August 17, 1998 & TPH \\
\hline T-2401-PILE & $\begin{array}{c}\text { Composite soil sample from } \\
\text { excavated impacted soil }\end{array}$ & $25-01-03$ & August 17,1998 & TPH \\
\hline T-2003-V** & $\begin{array}{c}\text { Verification soil sample, sodium } \\
\text { hydroxide spill }\end{array}$ & $25-01-01$ & September 8,1998 & $500 \mathrm{mg} / \mathrm{kg}$ \\
\hline T-2003-BKG** & Background sample & $25-01-01$ & September 8,1998 & $\mathrm{pH}$ \\
\hline
\end{tabular}

* The samples do not contain diesel or waste oil but do have an unknown hydrocarbon at the stated concentrations that is consistent with a light weight oil.

** The sample number used should refer to tank T-2002 rather than T-2003. 
subsurface soils were stained a rust color from historical releases of the sulfuric acid. Based on visual observation of the subsurface soil and the area of the surface staining, it was assumed that the amount of sulfuric acid released exceeded the reportable quantity (RQ) of 454 kilograms $(\mathrm{kg})$ (1000 pounds [lbs]) as set forth in Appendix A of Title 49 CFR $\$ 172.11$. Nevada Division of Emergency Management (NDEM) Case Number 98-0819-3014 was assigned to the release. A copy of the Spill Notification Report has been included in Appendix B. The new site has been added to CAU 398, Area 25 Spill Sites, and is identified as CAS 25-44-04 in Appendix II of the FFACO and will be addressed at a later time.

\subsubsection{Sodium Hydroxide Tank, T-2002}

This tank was intact with a 7.6-centimeter $(\mathrm{cm})$ (3-inch [in]) layer of insulation on the exterior. The ACM covering the piping elbows was removed on July 27 and 28, 1998. Markings on the exterior of the tank indicated that the tank was empty. However, on August 10, 1998, during the removal of the sulfuric acid tank, a pipe was inadvertently opened at a flange at the bottom of the tank releasing approximately $380 \mathrm{~L}$ (100 gal) of liquid to the concrete slab below and surrounding soil. Based on a "worst case" scenario is was assumed that the weight of sodium hydroxide released exceeded the RQ of $454 \mathrm{~kg}(1000 \mathrm{lbs})$ and a Spill Notification Report (Appendix B) was completed and submitted to the NDEP. NDEM Case Number 98-0811-3001 was assigned to the release. An additional 2.3 cubic meters $\left(\mathrm{m}^{3}\right)\left(3\right.$ cubic yards $\left.\left[\mathrm{yd}^{3}\right]\right)$ of soil were removed on August 12, 1998, in response to this release.

The tank was removed from its supports on August 11, 1998, and transported to the Area $910 \mathrm{c}$ Landfill on August 17, 1998. The tank was filled with a sand slurry on August 18 and 19 to meet the void space requirement for the landfill, which is 10 percent or less of the tank volume.

\subsubsection{CAS 25-01-02: Diesel Fuel Tank, T-2001}

Tank T-2001 was a 79,000-L (21,000-gal) capacity steel tank used to store diesel fuel for a boiler located in Building 3320. The tank was situated in an upright position with a berm covering the

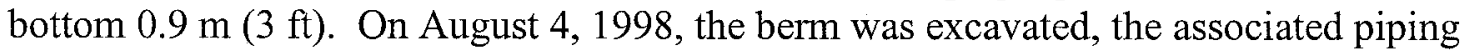
disconnected, and the tank lifted from its platform. The tank had been installed with its base placed directly on a $0.3-\mathrm{m}$ (1-ft) layer of gray, sandy gravel. Native soil, consisting of brown gravelly sands, are located directly below the gray layer. A 10-cm (4-in) steel drain pipe exited from the bottom of the tank and 5-cm (2-in) fill and vent lines entered at the top of the tank. There was no evidence that the tank itself, had leaked; the tank was intact and there was no soil staining. However, the sandy soil surrounding a valve connected to the drain pipe was moist and had a strong diesel odor. This drain is buried approximately $30 \mathrm{~cm}(1 \mathrm{ft})$ below ground surface (bgs).

Visual observations indicated that the area impacted was extensive. A sample was collected near the drain valve where the soil was moist and had a strong hydrocarbon odor. Two samples of the soil beneath the tank were collected; one immediately below the center of the tank and one at 


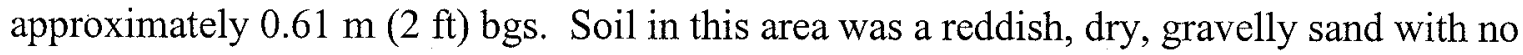
hydrocarbon odor. All three samples were submitted for laboratory analysis for TPH using EPA Method 8015 Modified. The results of this analysis are summarized in Table 1.

On August 10, 1998, an attempt was made to determine the extent of the plume. Approximately $10.7 \mathrm{~m}^{3}\left(14 \mathrm{yd}^{3}\right)$ of soil were removed and disposed of as a hydrocarbon waste based on process knowledge and field observations. One sample, collected at the end of the trench farthest away from the drain valve, was analyzed using a Petroflag® Hydrocarbon Analyzer field-screening test. The result of the field-screening test was 450 parts per million (ppm). Because the actual boundaries of the plume are unknown and appear to be quite extensive, it was concluded that additional excavation was beyond the scope of this project and excavation activities were halted. The new site has been added to CAU 398, Area 25 Spill Sites, and is identified as CAS 25-25-16 in Appendix II of the FFACO and will be addressed at a later time. A Spill Notification Report was completed and submitted to the NDEP on August 11, 1998 (Appendix B). The spill was assigned NDEM Case Number 98-0811-3002. Figure 4 contains "before" and "after" photographs of the site.

\subsubsection{CAS 25-01-03: Diesel Fuel Tank, T-2401}

This CAS consisted of tank T-2401, a 15,000-L (4,000-gal) capacity tank that was used to store diesel fuel for the emergency generators located next to Building 3324. Surface soil samples collected June 15, 1998, were analyzed for TPH. The results indicated possible historical releases to the soils with concentrations at 410,850 , and $920 \mathrm{mg} / \mathrm{kg}$, all of which are above the NDEP action level of $100 \mathrm{mg} / \mathrm{kg}$. However, these values may be attributable to leaching from the adjacent asphalt pad.

On August 3, 1998, the supports were cut and tank T-2401 was removed from the concrete stand. Excavation of the underlying soils was done on August 17, 1998. The Petroflag( $($ fieldscreening tests were done as the excavation advanced to help determine the quantity and concentration of hydrocarbons in the soil. Results ranged from 18 to $212 \mathrm{ppm}$. The area

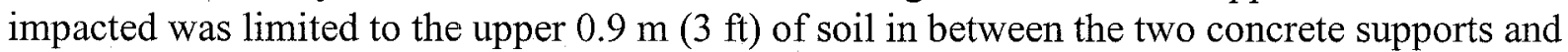
along the associated piping. Approximately $6.1 \mathrm{~m}^{3}\left(8 \mathrm{yd}^{3}\right)$ of soil were removed; however, the volume of soil that had a hydrocarbon concentration greater than the $100 \mathrm{mg} / \mathrm{kg}$ Action Level did not exceed the reportable limit of $2.3 \mathrm{~m}^{3}\left(3 \mathrm{yd}^{3}\right)$, therefore no spill notification was submitted.

The soil pile was transported to the U10c Landfill on September 21, 1998, and the excavation was backfilled with native soils on September 24, 1998. Figure 5 contains "before" and "after" photographs of the site.

\subsubsection{CAS 25-01-04: Charcoal Adsorption Furnace Tank, D-2001}

CAS 25-01-04 consisted of one 5,300-L (1,400-gal) capacity tank identified as a "charcoal adsorption furnace" associated with the water demineralization process (IT, 1997c). The tank 


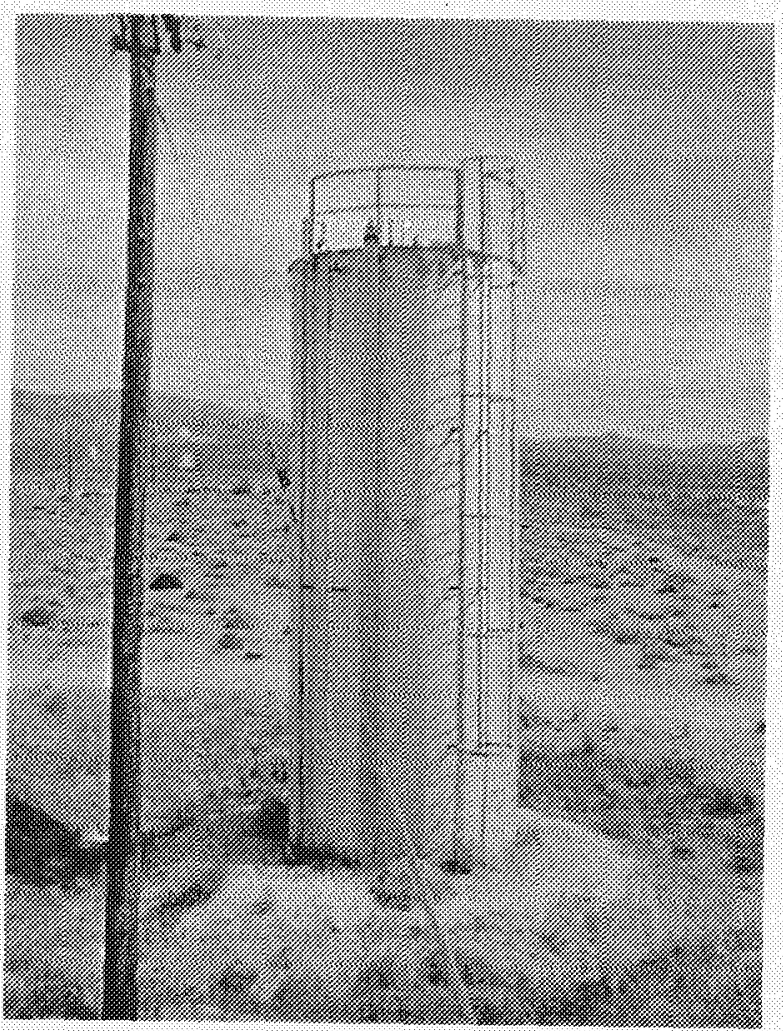

(Prior to closure activities)

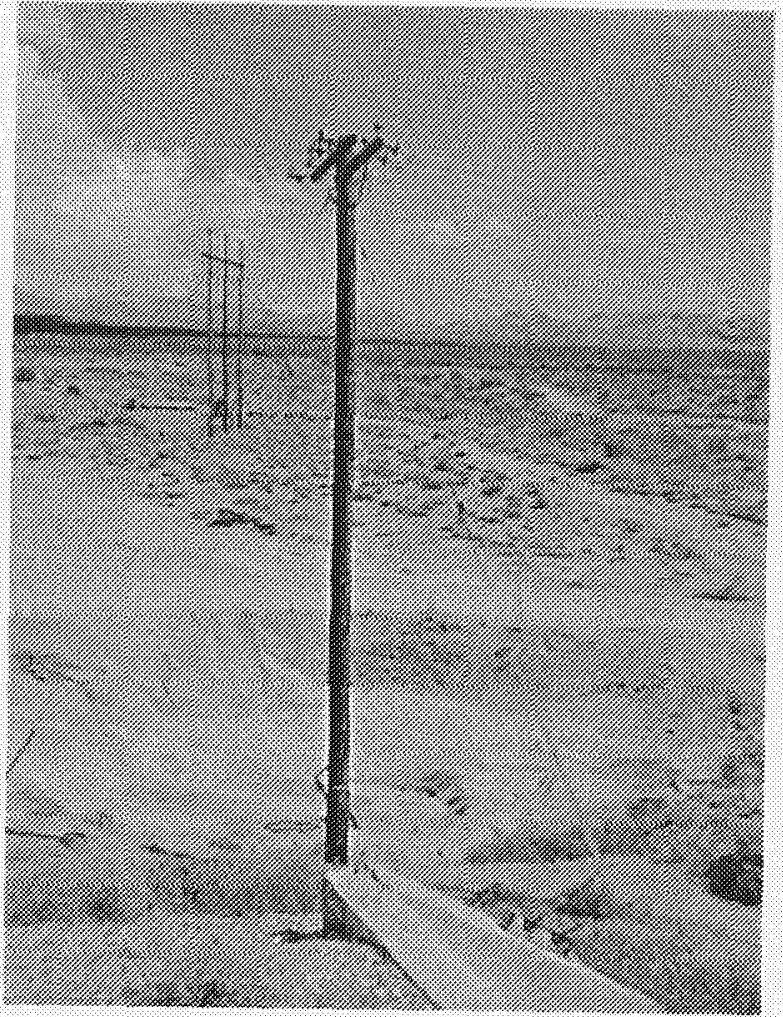

(Photographed September 8, 1998)

FIGURE 4

CAS 25-01-02: DIESEL FUEL TANK

(BN, 1998c) 
THIS PAGE INTENTIONALLY LEFT BLANK 


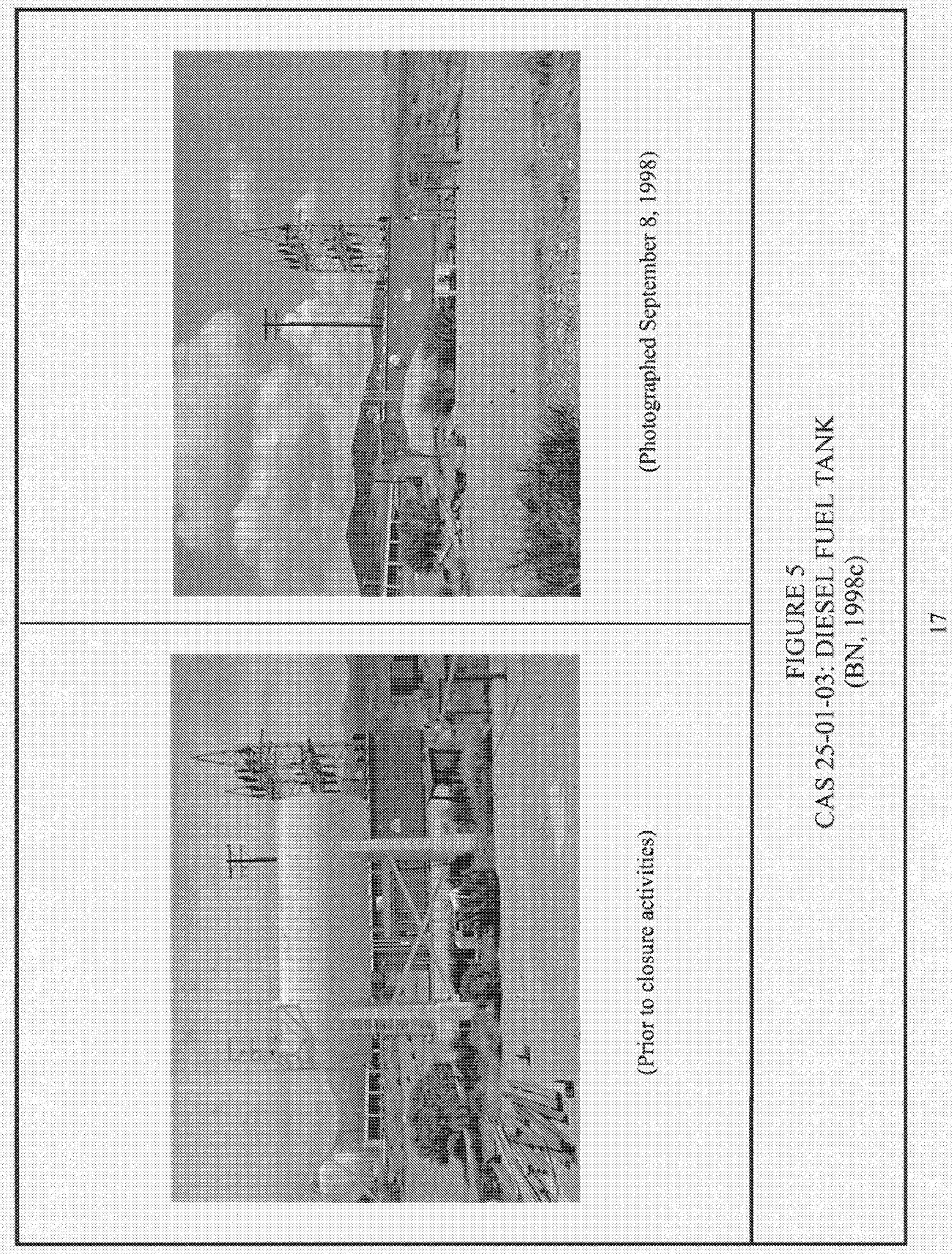


THIS PAGE INTENTIONALLY LEFT BLANK 
was situated atop a concrete pad located adjacent to Building 3320. The exterior condition of the tank was good. There was a 10-cm (4-in) utility water line feeding the tank, a 10-cm (4-in) dechlorinated water line from the tank to the demineralization plant, and one 10 -cm (4-in) pipe from the tank to a dirt-filled sump or drain just below the tank on the north side. The aboveground piping appeared to be in good condition; however, the pipe elbows and joints were insulated with an ACM. The ACM was removed on July 27 and 28, 1998. The bolts securing the tank to the concrete pad were cut on August 3,1998, and the tank removed on August 5, 1998, and transported to the 10c Landfill for disposal on August 10, 1998. Prior to disposal, a small hole was cut in the side of the tank to confirm that the content actually was a charcoal medium. Figure 6 contains "before" and "after" photographs of the site.

\subsubsection{CAS 25-01-08: Nalcool Tank}

CAS 25-01-08 consisted of one 300-L (80-gal) capacity storage container. The tank was originally identified at Building 4838, the former gas station, located in the Area 25 CSA. A site visit in July 1997, confirmed that the tank no longer exists at the site. Discussions with property management personnel indicated that the tank would not have been tracked with a property number since it did not cost enough to warrant tracking (IT, 1997d). A photograph of the tank, provided in the Reynolds Electrical \& Engineering Company, Inc. (REECo) Inventory of Inactive and Abandoned Facilities Waste Sites, shows that the tank was labeled as containing a mixture of antifreeze, water and Nalcool (REECo, 1991). No visible surface staining of the soil or concrete was observed during the July 1997 visit (IT, 1997d) or during the site visit on May 18, 1998. Figure 7 contains "before" and "after" photographs of the site.

\subsection{DEVIATIONS FROM THE APPROVED SAFER WORK PLAN}

There were two deviations from the approved SAFER Work Plan. The Work Plan specifies that the associated piping will be removed at all the sites; however, this was determined to be infeasible due to site condition. Piping was disconnected and cut flush with the concrete surface from tanks T-2002 and T-2003, in lieu of removal. The piping associated with tank D-2001 was cut flush with the building. The piping associated with the large diesel tank (CAS 25-01-02) was left in place and will be addressed in the closure activities for CAU 398. Only at tank T-2401 was the piping removed.

The second deviation was due to the unexpected release of sodium hydroxide from tank T-2002, CAS 25-01-01.

\subsection{CORRECTIVE ACTION SCHEDULE AS COMPLETED}

Closure activities were completed on schedule with no significant delays being attributed to the unexpected release of sodium hydroxide or the historical hydrocarbon release sites. Field work, 
sampling, and the majority of the waste management activities were completed between July 27, 1998, and August 19, 1998. On August 21, 1998, after receiving the analytical data for the tank T-2401 verification samples, the excavated soil was transported to the 10c Landfill and the excavation was backfilled with native soil. Table 2 provides the project schedule for the completed field activities.

\subsection{SITE PLAN}

Figure 2 is a site vicinity map depicting the location of each CAS located at the ETS facility. Since no modifications to subsurface utilities or facilities were made, engineering "as-builts" were not required. A note will be attached to the engineering drawing indicating that the tanks have been removed. 


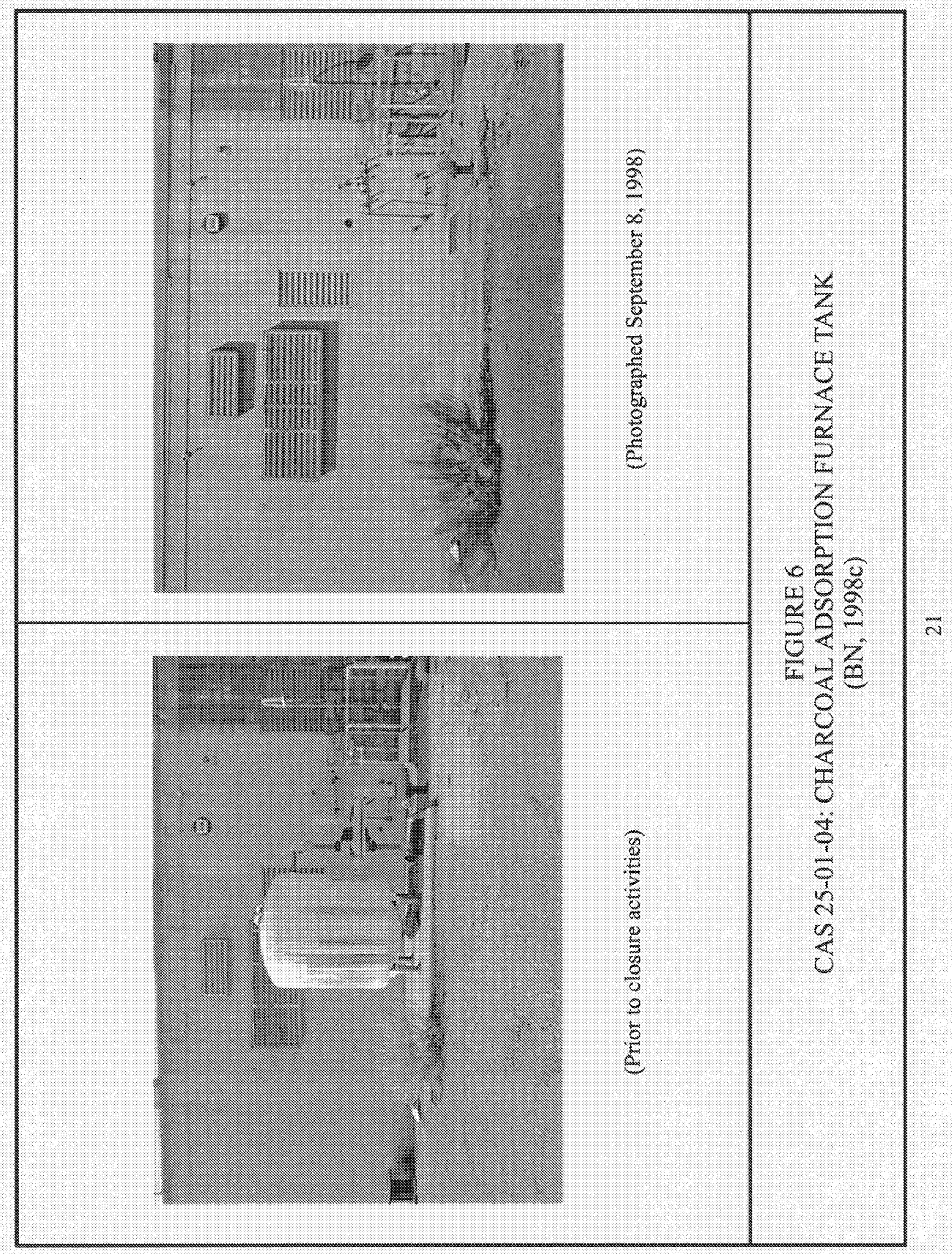




\section{THIS PAGE INTENTIONALLY LEFT BLANK}




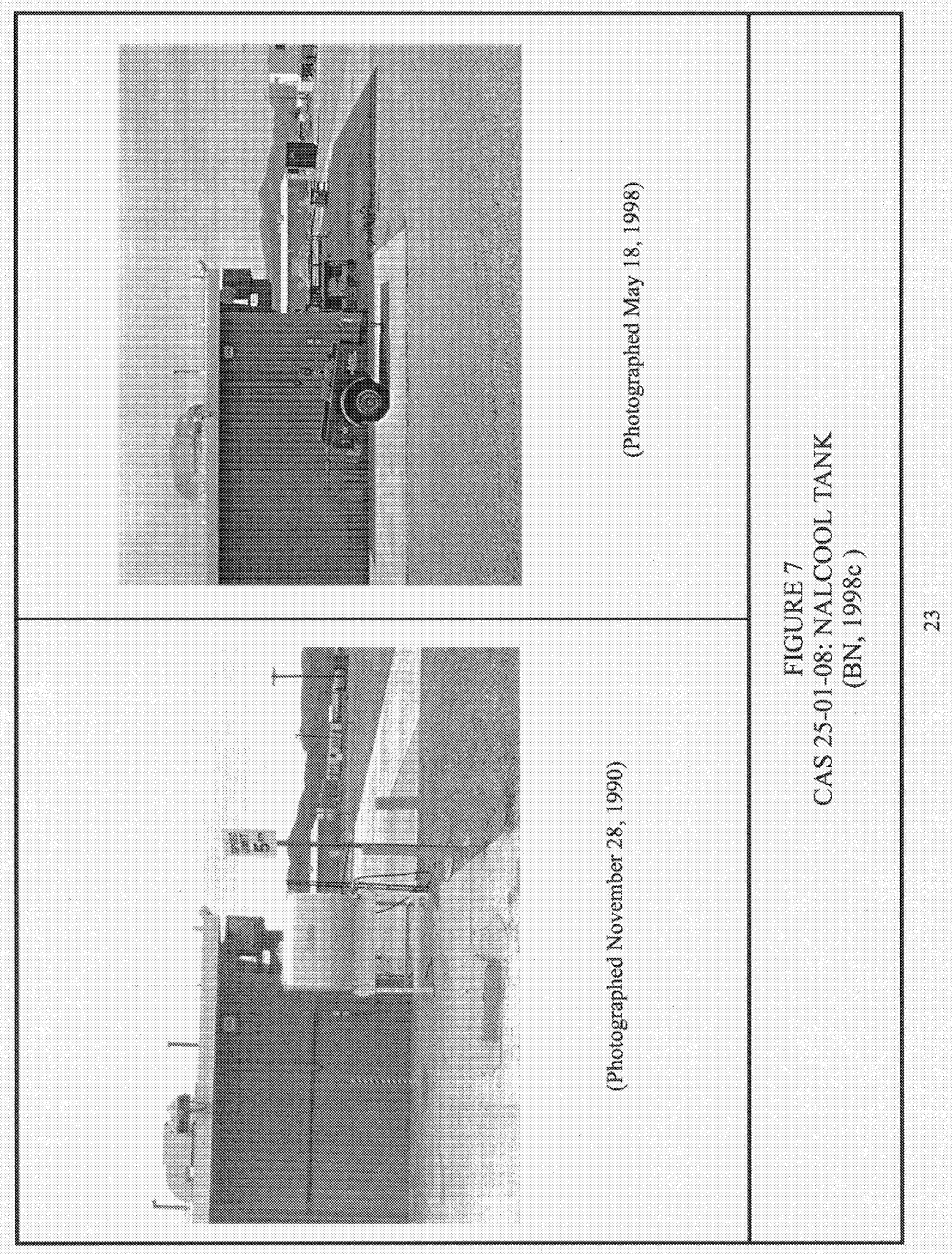


THIS PAGE INTENTIONALLY LEFT BLANK 
TABLE 2 - ACTIVITY SCHEDULE

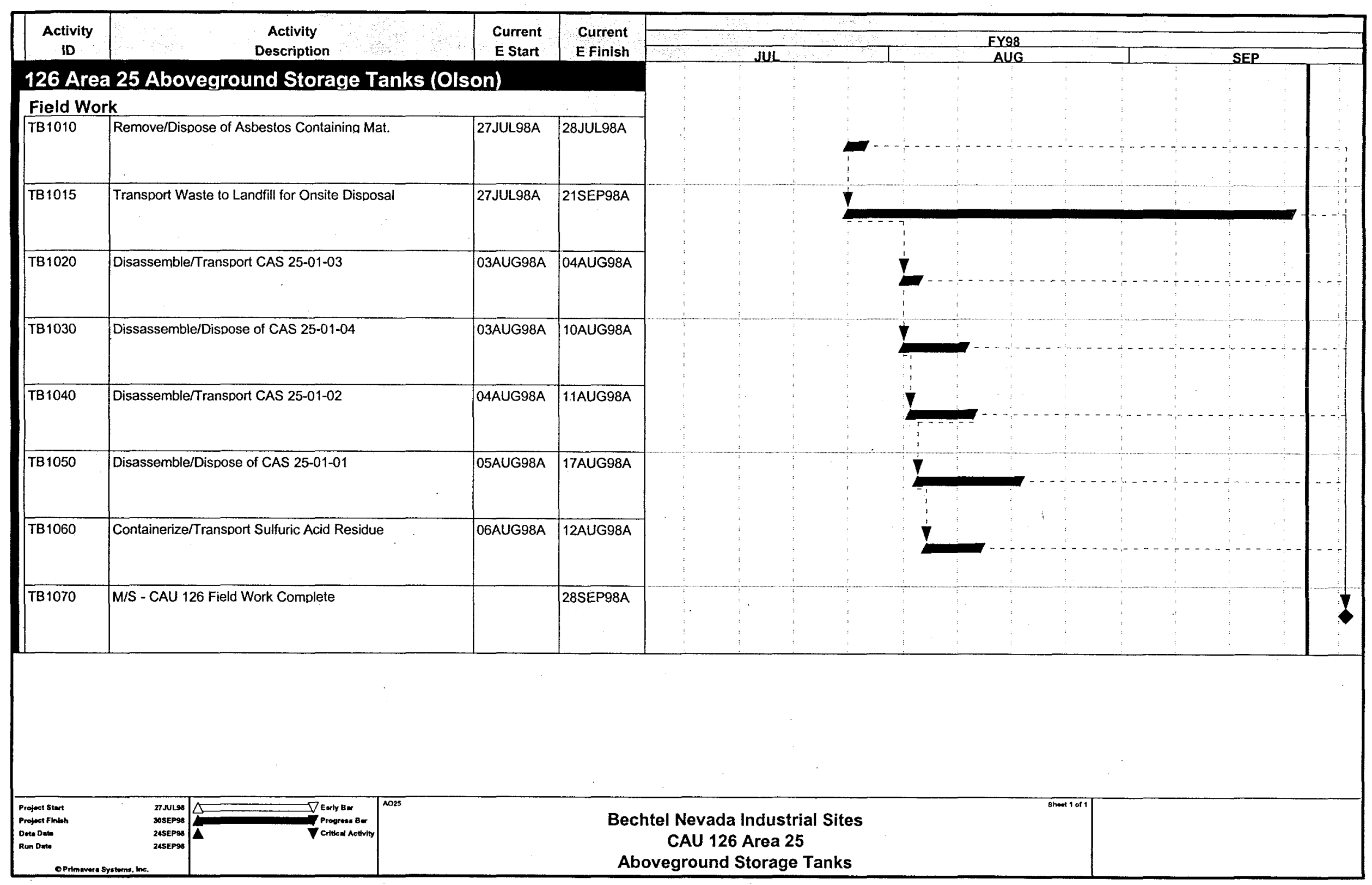


THIS PAGE INTENTIONALLY LEFT BLANK 


\subsection{WASTE DISPOSITION}

Waste generated from the closure activities consisted of:

- Asbestos-containing material.

- Sulfuric acid residue and associated impacted soil.

- Petroleum hydrocarbon-impacted soils.

- Sanitary waste.

A Material Clearance tag or "green tag" was issued for each load of material leaving the site. The two diesel tanks that were of value were sent to the Area 23 Salvage Yard for sale or reuse. Copies of the waste disposal documents have been included in Appendix C.

\subsection{ASBESTOS-CONTAINING MATERIAL}

The insulation on the elbows of the piping associated with CAS 25-01-01 and 25-01-04 was an ACM in a friable state. Trained asbestos workers sprayed the material with an encapsulating substance, wrapped each elbow in plastic, cut the pipe with a torch, and placed the piece in a 208 $\mathrm{L}$ (55 gal) drum. A total of four drums and one piece, too large for a drum, were generated. The items were properly labeled and on August 6, 1998, they were transported to the Area 23

Sanitary Landfill with the required chain-of-custody.

\subsection{SULFURIC ACID RESIDUE}

The sulfuric acid residue was placed in 208-L (55-gal), lined, steel drums. The cleanup began on August 10, 1998, and was completed on August 12, 1998. A total of ten drums were filled. This nonhazardous material was transported to the Area 9 10c Sanitary Landfill on August 17, 1998. An additional $2.3 \mathrm{~m}^{3}\left(3 \mathrm{yd}^{3}\right)$ of soil were removed from the drainage area where the soil was obviously stained from past releases.

\subsection{PETROLEUM HYDROCARBON-IMPACTED SOIL}

Soil that was impacted with petroleum hydrocarbons was excavated, placed in a dump truck, and hauled to the Area $910 \mathrm{c}$ Sanitary Landfill. A total of $10.7 \mathrm{~m}^{3}\left(14 \mathrm{yd}^{3}\right)$ of soil were excavated from CAS 25-01-02 tank location and approximately $6.1 \mathrm{~m}^{3}\left(8 \mathrm{yd}^{3}\right)$ of soil were excavated from the CAS 25-01-03 tank location. 


\subsection{SANITARY WASTE}

Sanitary waste consisted primarily of demolition debris. The waste was placed in scrap dumps or flat bed trucks and transported to the Area 9 10c Sanitary Landfill. The waste included:

- Tank T-2002, the sodium hydroxide tank and T-2003, the sulfuric acid tank (CAS 25-01-01).

- Tank D-2001, the charcoal adsorption tank (CAS 25-01-04).

- Demolition debris, i.e., concrete rebar, piping, insulation, scrap metal, etc.

- Personal protective equipment, i.e., tyveks, gloves, etc.

A small amount of water was used to decontaminate the boots and gloves of the personnel cleaning up the acid residue. This water was either allowed to evaporate or was solidified with native soil and disposed of with other soil removed from the site.

Tanks T-2001 (CAS 25-01-02) and T-2401 (CAS 25-01-03) were of value and were transported to the Area 23 Salvage Yard for reuse. 


\subsection{CLOSURE VERIFICATION RESULTS}

\subsection{CAS 25-01-01: SULFURIC ACID AND SODIUM HYDROXIDE TANKS}

The removal of tanks T-2002 and T-2003 began on August 5, 1998, and was completed on August 19, 1998. The tanks and all associated waste were disposed of as a nonhazardous waste. Associated piping was cut flush with the ground surface. Regulated substances were not associated with the tank; therefore, no verification activities were conducted with respect to this CAS. However, a sample was collected after removing the soil impacted by the sodium hydroxide spill and analyzed for $\mathrm{pH}$. The verification sampling results indicate a soil $\mathrm{pH}$ of 2.99 ; therefore further action is not required with respect to the sodium hydroxide spill. When this value is compared with 7.58 , the $\mathrm{pH}$ of a background soil sample, it indicates that further investigation of releases from the sulfuric acid tank will be required. The release site is identified as CAS 25-44-04 included in CAU 398 Area 25 Spill Sites.

\subsection{CAS 25-01-02: DIESEL FUEL TANK}

There was no evidence that the tank itself, had leaked; the tank was intact and there was no soil staining. However, the sandy soil surrounding a valve connected to the drain pipe was moist and had a strong diesel odor. This drain is buried approximately $30 \mathrm{~cm}(1 \mathrm{ft})$ below ground surface (bgs). Excavation was undertaken to determine the extent of the plume.

Visual observations indicated that the area impacted was extensive. A sample was collected near the drain valve where the soil was moist and had a strong hydrocarbon odor. Two samples of the soil beneath the tank were collected; one immediately below the center of the tank and one at

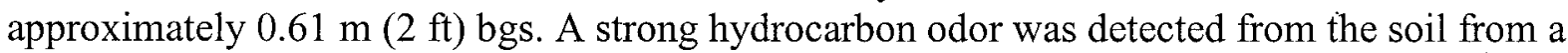
valve connected to the drain pipe. One sample, collected at the end of the trench farthest away

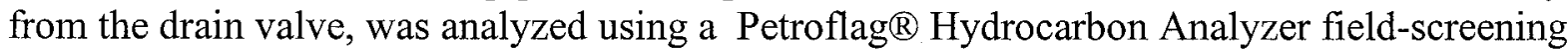
test. The result of the field-screening test was 450 parts per million (ppm). Because the actual boundaries of the plume are unknown and appear to be quite extensive, it was concluded that additional excavation was beyond the scope of this project and excavation activities were halted. The new site has been added to CAU 398, Area 25 Spill Sites, and is identified as CAS 25-25-16 in Appendix II of the FFACO and will be addressed at a later time. The associated piping with this tank was not removed.

\subsection{CAS 25-01-03: DIESEL FUEL TANK}

Tank T-2401 was removed from its supports on August 3, 1998, and transported to the Area 23 Salvage Yard on August 4, 1998. The piping and approximately $6 \mathrm{~m}^{3}\left(8 \mathrm{yd}^{3}\right)$ of soil were 
removed. Three samples were collected from the bottom of the excavation to ensure that the site had been cleaned up to acceptable levels. One composite sample of the soil pile was collected for waste determination. Hydrocarbons were not detected $(<20 \mathrm{mg} / \mathrm{kg})$ in the three verification samples; however, the concentration was $500 \mathrm{mg} / \mathrm{kg}$ for the soil pile. The soil pile was transported to the U10c Landfill on September 21, 1998, and the excavation was backfilled with native soils on September 28, 1998. It is recommended that no further action be taken at this site and that it should be considered "clean closed."

\subsection{CAS 25-01-04: CHARCOAL ADSORPTION FURNACE TANK}

Tank D-2001 was removed on August 3, 1998, and disposed of as sanitary waste. The piping was cut flush with the building. Regulated substances were not associated with the tank and there were no know releases; therefore, no verification activities were conducted. Further action is not required with respect to this site.

\subsection{CAS 25-01-08: NALCOOL TANK}

Since this tank had already been removed and there is a high degree of confidence that the tank contained only an antifreeze mixture, which is not a regulated material, it is proposed that the site be closed with no further action. 


\subsection{CONCLUSIONS AND RECOMMENDATIONS}

\subsection{CONCLUSIONS}

Closure of this site was achieved by completing the following activities:

- Removing the ACM on the piping associated with CAS 25-01-01 and 25-01-04.

- Containerizing the sulfuric acid residue associated with CAS 25-01-01.

- Dismantling the tanks, disconnecting or removing the piping, and demolishing the support structures, where applicable.

- Excavating impacted soils.

- Collecting samples for waste characterization and site evaluation purposes.

- Disposing of all waste.

- Documenting all activities.

\subsection{RECOMMENDATIONS}

Based on the completion of site activities, it is requested that a Notification of Completion be provided by the NDEP for CAU 126. Upon closure approval, CAU 126 will be promoted from Appendix III of the FFACO to Appendix IV, "Closed Corrective Action Units." 


\subsection{REFERENCES}

BN, see Bechtel Nevada.

Bechtel Nevada, 1998a, Site-Specific Health and Safety Plan for SAFER Closure Area 25 Aboveground Storage Tanks, Engine Test Stand, Nevada Test Site, Las Vegas, Nevada.

Bechtel Nevada, 1998b, Field Management Plan for Corrective Action Unit No. 126 SAFER Closure of Area 25 Aboveground Storage Tanks, Nevada Test Site, Nevada, Las Vegas, Nevada.

Bechtel Nevada, 1998c, Digital Photos

CFR, see Code of Federal Regulations.

Code of Federal Regulations, 1997, Characteristics of Hazardous Waste, Title 40 CFR 261

Subpart C, Office of the Federal Register National Archives and Records Administration, Washington, D.C.

Code of Federal Regulations, 1997, Hazardous Material Table and Special Provisions, Title 49 CFR 172, Subpart B, Office of the Federal Register National Archives and Records Administration, Washington, D.C.

DOE, see U.S. Department of Energy.

DOE/NV, see U.S. Department of Energy, Nevada Operations Office.

EPA, see U.S. Environmental Protection Agency.

U.S. Environmental Protection Agency, 1996, Test Methods for Evaluating Solid Waste Physical/Chemical Methods, SW-846, Third Edition, Washington, D.C. Government Printing Office.

FFACO, see Federal Facility Agreement and Consent Order.

Federal Facility Agreement and Consent Order, 1996, Agreed to by the Nevada Division of Environmental Protection, the U.S. Department of Energy, and the U.S. Department of Defense.

IT, see IT Corporation. 
IT Corporation, 1997a, Preliminary Assessment for CAU No. 126: Area 25 Aboveground Storage Tanks, CAS No. 25-01-01: Aboveground Storage Tanks (2) Nevada Test Site, Nevada, Preliminary Report, Las Vegas, Nevada.

IT Corporation, 1997b, Preliminary Assessment for CAU No. 126: Area 25 Aboveground Storage Tanks, CAS No. 25-01-03: Aboveground Storage Tank, Nevada Test Site, Nevada, Preliminary Report, Las Vegas, Nevada.

IT Corporation, 1997c, Preliminary Assessment for CAU No. 126: Area 25 Aboveground Storage Tanks, CAS No. 25-01-04: Aboveground Storage Tank, Nevada Test Site, Nevada, Report, Las Vegas, Nevada.

IT Corporation, 1997d, Preliminary Assessment for CAU No. 126: Area 25 Aboveground Storage Tanks, CAS No. 25-01-08: Aboveground Storage Tank, Nevada Test Site, Nevada, Preliminary Report, Las Vegas, Nevada.

IT Corporation, 1998, Preliminary Assessment for CAU No. 126: Area 25 Aboveground Storage Tanks, CAS No. 25-01-02: Aboveground Storage Tank, Nevada Test Site, Nevada, Las Vegas Nevada.

NAC, see Nevada Administrative Code.

Nevada Administrative Code, 1996, Chapter 459.9973, Presence of Excessive Petroleum in Soil: Evaluation; Assessment of Risk; Corrective Action, Carson City, Nevada: Nevada Division of Environmental Protection.

REECo, see Reynolds Electrical \& Engineering Company, Inc.

Reynolds Electrical \& Engineering Company, Inc., 1991, Inventory of Inactive and Abandoned Facilities Waste Sites, Las Vegas, Nevada.

U.S. Department of Energy, Nevada Operations Office, 1994, Nevada Environmental Restoration Project, Project Management Plan, Rev.0, Las Vegas, Nevada.

U.S. Department of Energy, Nevada Operations Office, 1996a, Nevada Environmental Restoration Project, Industrial Sites Quality Assurance Project Plan, Nevada Test Site, Nevada, Rev.1, DOE/NV--372, Las Vegas, Nevada.

U.S. Department of Energy, Nevada Operations Office, 1996b, Final Environmental Impact Statement for the Nevada Test Site and Off-Site Locations in the State of Nevada, Volume 1, Chapters 1-9, DOE/EIS 0243, Las Vegas, Nevada. 
U.S. Department of Energy, Nevada Operations Office, 1998a, Nevada Environmental Restoration Project, Health and Safety Plan, Rev.3, Las Vegas, Nevada.

U.S. Department of Energy, Nevada Operations Office, 1998b, Streamlined Approach for Environmental Restoration Work Plan for Corrective Action Unit 126: Closure of Aboveground Storage Tanks, Nevada Test Site, Nevada, DOE/NV/11718-230, UC-702. Las Vegas, Nevada. 


\section{APPENDIX A}

\section{SPILL NOTIFICATION REPORTS}




\section{THIS PAGE IS INTENTIONALLY LEFT BLANK}


NDEM Case Number

98-0811-3001 
THIS PAGE IS INTENTIONALLY LEFT BLANK 


\section{SPILL NOTIFICATION REPORT}

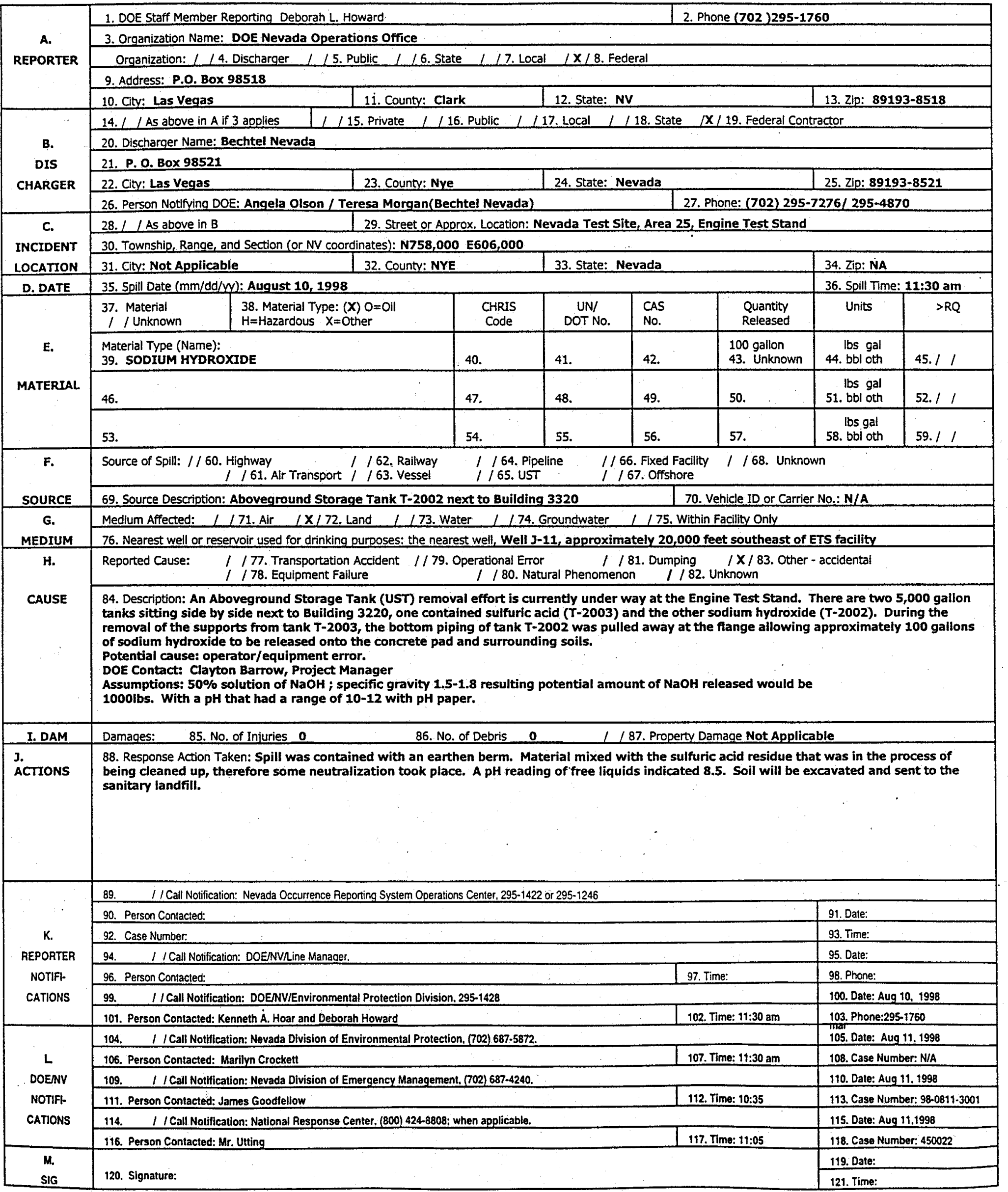


THIS PAGE IS INTENTIONALLY LEFT BLANK 
NDEM Case Number

98-0811-3002 
THIS PAGE IS INTENTIONALLY LEFT BLANK 
THIS PAGE IS INTENTIONALLY LEFT BLANK 
NDEM Case Number

98-0811-3014 
THIS PAGE IS INTENTIONALLY LEFT BLANK 


\section{SPILL NOTIFICATION REPORT}

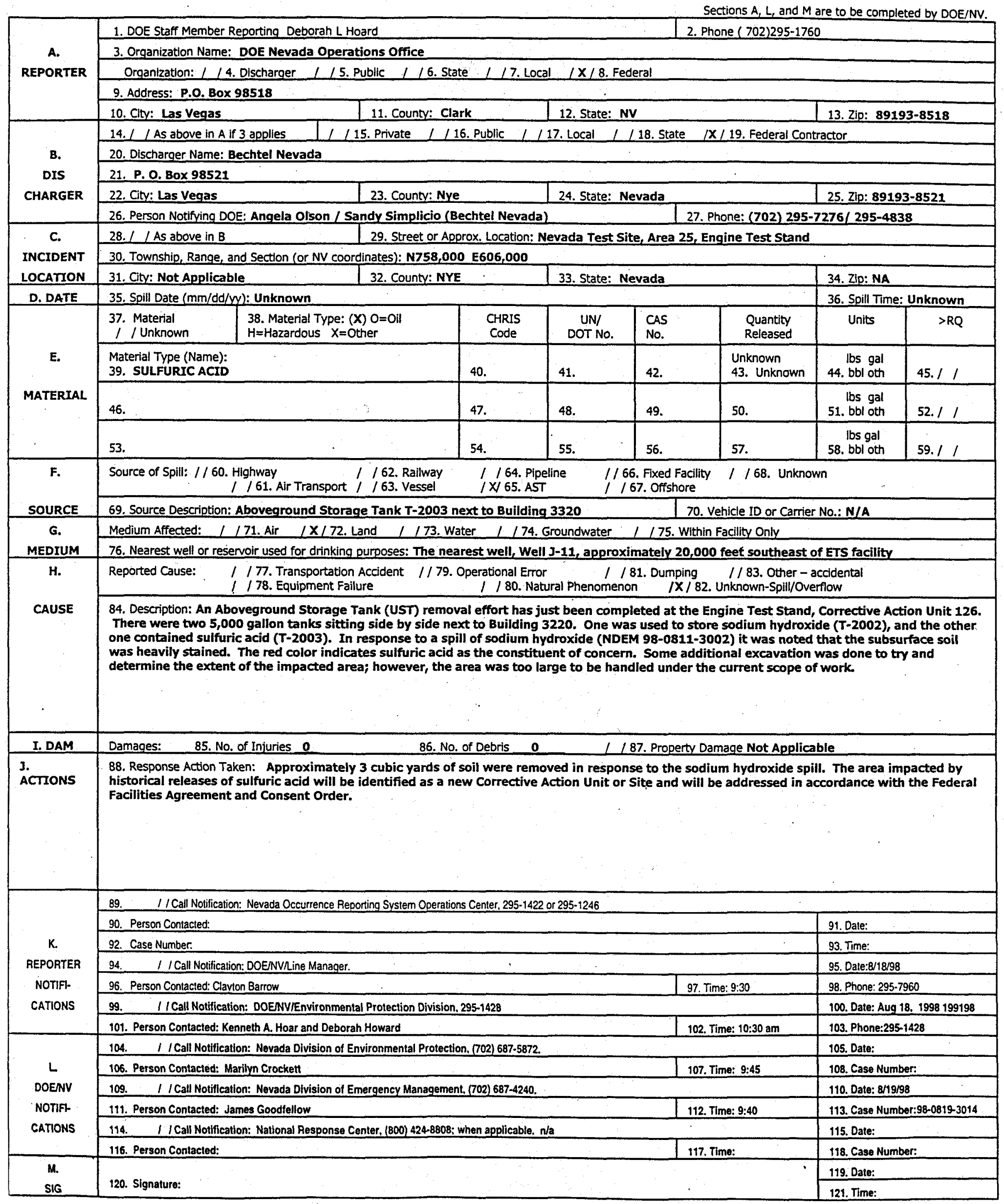


THIS PAGE IS INTENTIONALLY LEFT BLANK 


\section{APPENDIX B}

\section{LABORATORY ANALYTICAL DATA}


THIS PAGE IS INTENTIONALLY LEFT BLANK 


\section{Preliminary Surface Soil Samples}

CAS 25-01-03

May 11, 1998 
THIS PAGE IS INTENTIONALLY LEFT BLANK 
Lab Name:

OUANTERRA Yo

Contract:

625.01

Lab Code:, Imfo Case No.:

SAS NO.:

SDG NO.:

V413

Matrix : (Boil/water)

sorr.

Lab Sample ID:

17809-002

Sample wt/vol: $30.0 \quad(9 / m I)$

Lab Fize ID:

Level = (Low/med)

ION

Date Sampied:

$05-12-98$

y Molsturẹ not dec. dec.

Date Extracted:

$05-20-28$

Date Amalyred:

$06-11-99$

Extraction: (SepF/Conr/Sonc/shak) Sone

Dilution Factor:

1.0

GPC Cleanup: (Y/N) N N $\mathrm{NH}$

Dilution ractore

1.0

CONCENTRATION UNITS: .

CAS NO.

compound

(mg/L or $\mathrm{mg} / \mathrm{kg})$ ma/xg
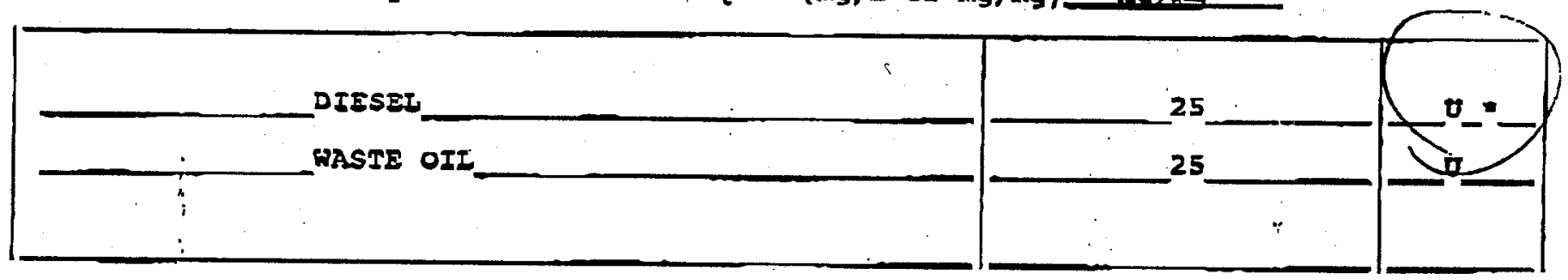

U: concentration of analyte is less than the value given.

* Unknown hydrocarbon found at $410 \mathrm{mg} / \mathrm{kg}$. 
Lab same: OUANTERRA MO

contraee:

625.02

Iab code: ITMO Case No.: :

Marrix : (soil/wacer) SOIL

SAS NO.: SDG Nंo.

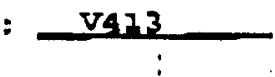

Iab Sample ID: $17809-002$ Iab File ID: sample wr/vol: $20.1 \quad(\mathrm{~g} / \mathrm{mI})$ G Level: $\quad$ (low/med) INW Dace Sampled: $05-11-98$

* Modsture: nor dec. des. Date sxtraced: $05-20-98$ Exíraceson: (sepg/Conc/Sone/Shak) ___sone GPC Cleante: $(\mathrm{X} / \mathrm{N}) ـ \mathrm{~N}$ 요 Dace Analyzed: $06-17-98$ Dilution Factor: 2.0 CONCENIRATION ONITS: (mg/L or $\mathrm{mg} / \mathrm{Kg}$ ) $\mathrm{me} / \mathrm{Ka}$ Cas No. Corpound

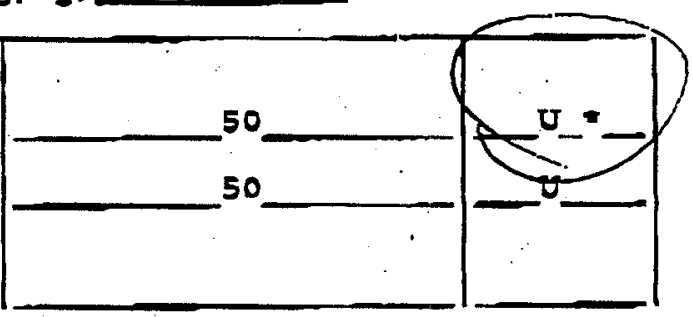

$U$ : Concentriaion of andyce is less than the value given. unknown hyarocarbon found at $650 \mathrm{mg} / \mathrm{kg}$. 


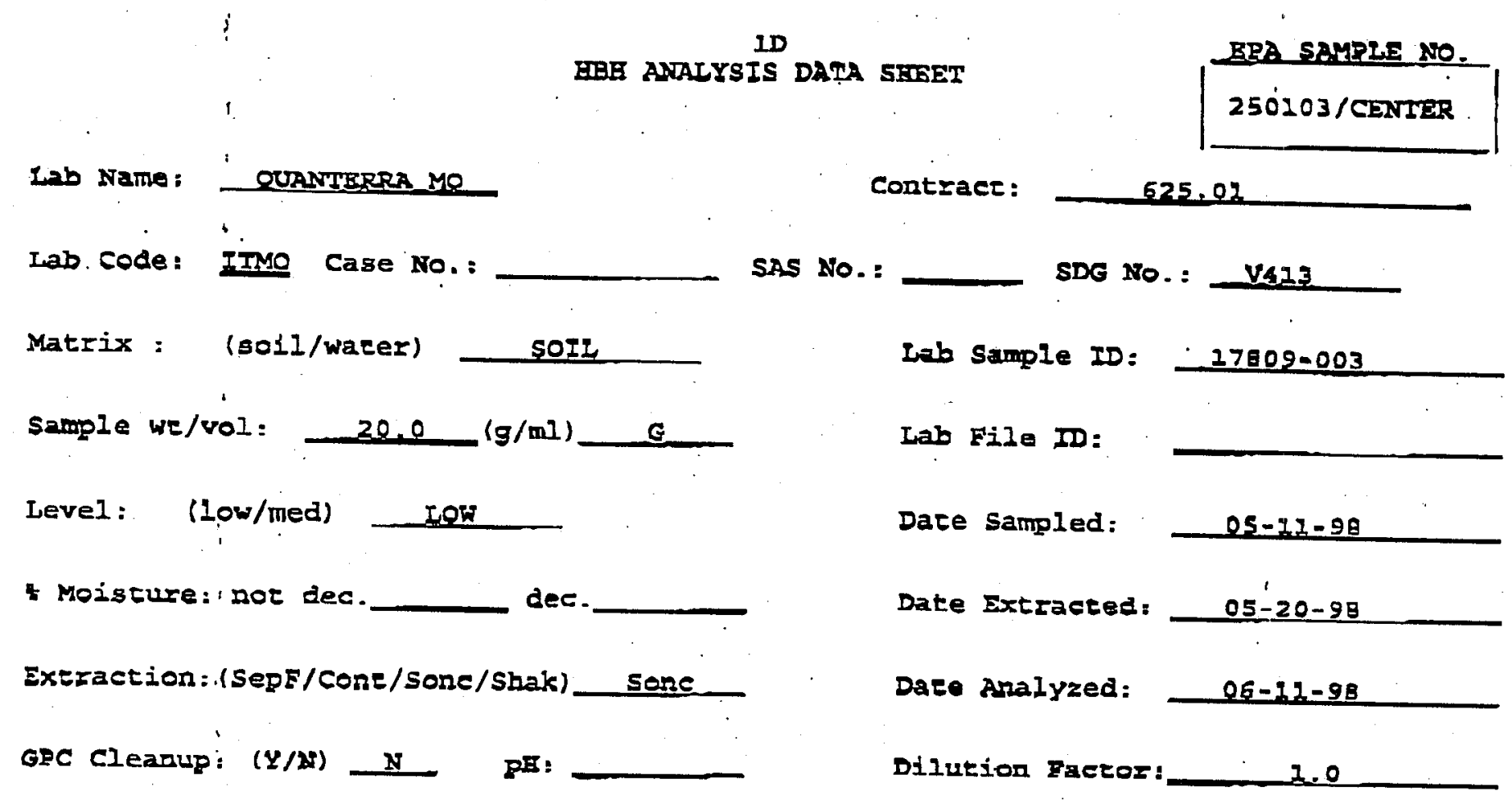

CAS NO. compound CONCRATRATION UNITS: (mg/L or $\lg / \mathrm{Kg}$ ) $\mathrm{ma} / \mathrm{Rg}$.

DIESEL_LASTE OIL_L

U: Concentration of analyte ig less than the value given.

: Unknown. hydrocarbon lound at $920 \mathrm{mg} / \mathrm{kg}$. 
THIS PAGE IS INTENTIONALLY LEFT BLANK 
Preliminary Sulfuric Acid Residue Sample

CAS 25-01-02

June 15, 1998 
THIS PAGE IS INTENTIONALLY LEFT BLANK 
1 INORGANIC ANALYSES DATA SHEET
EPA SAMPLE NO.

ETS-T-2003 ab Name: QUANTERRA_MO

ab code: ITMO_ Case NO. Matrix (soil/water) : WATER Level (low/med): LOW.

Contract: 625.01

SAS NO.:

SDG NO.: V441

Lab Sample ID: P18190-001

Date Received: 06/22/98

Solids:

0.0

Concentration Units (ug/L or $\mathrm{mg} / \mathrm{kg}$ dry weight): UG/L_

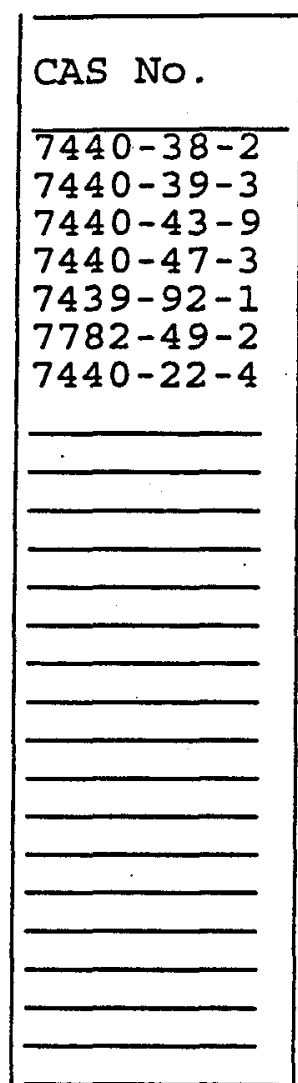

olor Before:

olor After:

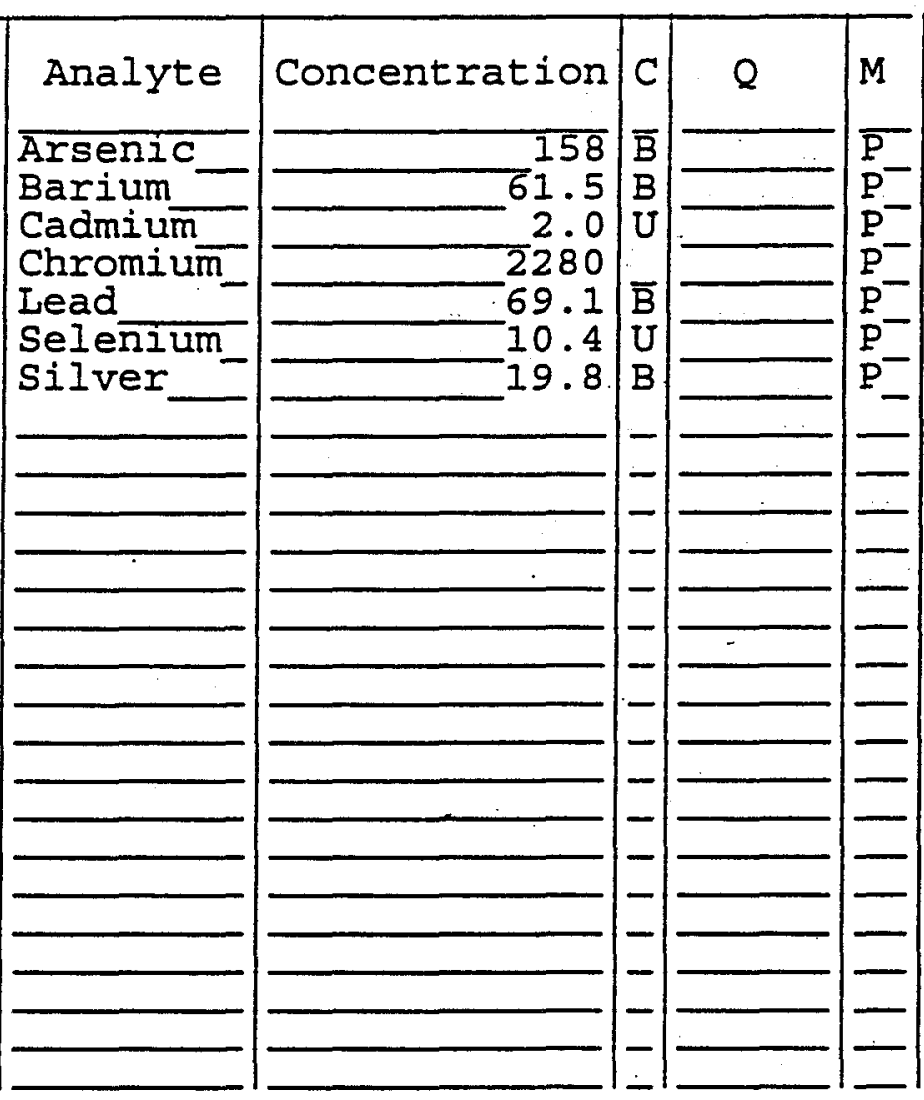

Clarity Before:

Texture :

Clarity After:

Artifacts : smments : 
THIS PAGE IS INTENTIONALLY LEFT BLANK 
Soil Samples

CAS 25-01-02

August 4, 1998 
THIS PAGE IS INTENTIONALLY LEFT BLANK 
NEL LABORATORIES

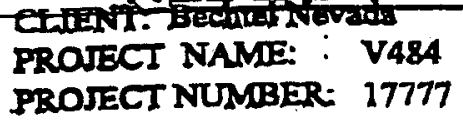

TEST: $\quad$ Total Ermactoble Petroleum Hydrocerbons by IPA Method $8015 \mathrm{M}$, July 1992

METHOD: EPA 8015M

MATRDC: Solid

ANALYST: RLA

\begin{tabular}{|c|c|c|c|c|c|c|c|c|c|}
\hline $\begin{array}{l}\text { ClakNT } \\
\text { SAMPLE ID }\end{array}$ & $\begin{array}{l}\text { SAMTLE } \\
\text { DATE }\end{array}$ & $\begin{array}{c}\text { NEL } \\
\text { SAMPLE ID }\end{array}$ & $\begin{array}{c}\text { RESULT } \\
\text { mo/kg }\end{array}$ & $\underline{\text { C.R }}$ & $\begin{array}{l}\text { Reporting } \\
\text { Limit }\end{array}$ & $\begin{array}{l}\text { Surroga } \\
\text { Recover }\end{array}$ & & & ANALYZED \\
\hline T-2001-Valve & $8 / 4 / 98$ & L9808049-01 & $11000^{\circ}$ & DO & 150. mg/kg & D & $\%$ & $8 / 7 / 98$ & $8 / 13 / 98$ \\
\hline$T-2001-0$ & $8 / 4 / 98$ & L9808049-02 & 2500 & DO & 150. mg/kg & $\mathbf{D}$ & $\%$ & $8 / 7 / 98$ & $8 / 13 / 98$ \\
\hline$T-2001-2$ & $8 / 4 / 98$ & L9808049-03 & 340 & DO & 15. mg/kg & 104 & $\%$ & $8 / 7 / 98$ & $8 / 13 / 98$ \\
\hline
\end{tabular}

\section{CR: Carbon Ranes}

DO Diesel Rimge Organies (C12 to C34) and Oil Range Organics (C12 to C38).

Note: The reporting limit for OAl Renge Organics in soil is $50 \mathrm{me} / \mathrm{kg}$.

QUALITY CONIROL DATA (Total for Gas and Diesel Range):

Squple ID

Blenk, 080798-El -BLK

LCS, 080798-El - LCS

LCSD 080798-E1 - LCSD

MSD, 080798-EL - MSD
Result Acceptable Ranre Suroorate Recovent Sapale Number

$\begin{array}{llllll}\text { NP } & < & 15 . \operatorname{mg} / \mathrm{K} & 77 \% & \text { NA } \\ 94 \% & 79 & -117 \% & 79 \% & \text { NA } \\ 97 \% & 79 & -117 \% & 98 \% & \text { NA } \\ 117 \% & 70 & -120 \% & 110 \% & \text { L9808055-01 }\end{array}$

ND - Not Deteeted

+Surroprte aned was o-Texphenyh acceptance limalts 65-135\%.

This report shall not be reproduced exept in full, without the written approval of the laboraray. 
THIS PAGE IS INTENTIONALLY LEFT BLANK 
Verification Samples

CAS 25-01-03

August 17, 1998 
THIS PAGE IS INTENTIONALLY LEFT BLANK 
NEL LABORATÓRIES

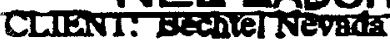

PROJECT NAME: V489

PROJECT NUMBER: 17777

TEST: Total Extractable Petroleum Hydrocarbons by EPA Method 801SM, July 1992

METHOD; EPA 8015M

MATRD: Solid

ANALYST: Scott

\begin{tabular}{|c|c|c|c|c|c|c|c|}
\hline $\begin{array}{l}\text { CLIENT } \\
\text { SAMPLE ID }\end{array}$ & $\begin{array}{c}\text { SAMPLE } \\
\text { DATE }\end{array}$ & $\begin{array}{c}\text { NEL } \\
\text { SAMPLE ID }\end{array}$ & $\begin{array}{c}\text { RESULT } \\
\text { mg/kg } \\
\end{array}$ & C.R. & $\begin{array}{l}\text { Reporting } \\
\text { Limit } \\
\end{array}$ & $\begin{array}{l}\text { Surrognte }: \\
\text { Recovery" EXTRACIED }\end{array}$ & \\
\hline$T-2401-3 S$ & $8 / 17 / 98$ & L.9808190-01 & ND & & 20. meskg & $112 \%$ & $8 / 20 / 98$ \\
\hline
\end{tabular}

$T-24013 \mathrm{~N}$

8/17/98 L9808190-02 ND

20. $\mathrm{mg} / \mathrm{kg}$

$118 \% \quad 8 / 18 / 98$

$8 / 20 / 98$

T-2401-3 Pipe

8/17/98 L9808190-03 ND J

20. magke

$136 \% \quad 8 / 18 / 98$

$8 / 20 / 98$

T-2401-Pile

$8 / 17198 \quad$ L9808190-04 500.Jm D

$20 . \mathrm{mg} / \mathrm{kg}$

$114 \% \quad 8 / 18 / 98$

$8 / 20 / 98$

\section{CR: CarbonRonge}

D Diesel Range Organics (C12 to C34).

Note: The reporting limit for Oil Range Organics in soil is $50 \mathrm{mg} / \mathrm{kg}$ QUALITY CONTROL DATA (Total for Gas word Dlesel Range):

sample ID

Blink, 980818 phs -BLK

LCS, 980818phs - LCS

MS, 980818 phs - MS

MSD, 980818tphs - MSD .
Resnlt Acceptable Range Surnopate Recovery Sample Number

$\begin{array}{llllll}\text { ND } & < & 20 . \mathrm{mg} / \mathrm{kg} & 127 \% & \text { NA } \\ 92 \% & 55-102 \% & 122 \% & \text { NA }\end{array}$

$39 \% \quad 38-107 \% \quad 113 \%$

L9808190-04

L9808190-04

ND - Not Detected

-Surrogate used was Oetacosane, acceptance livaits 54-130\% for sollds, 60-121\% for aqueous samples This repart shall not bs reproduced acept in full, without the written approval of the laboratory. 
THIS PAGE IS INTENTIONALLY LEFT BLANK 
Verification Sample, Sodium Hydroxide Spill Cleanup

CAS 25-01-01

September 8, 1998 
THIS PAGE IS INTENTIONALLY LEFT BLANK 
Building A-2, Receiving

North Las Vegas, NV 89030-4129

Project: 625.01

Category: $\mathrm{pH}$

Method: EPA 9045

Matrix: Soil
Sample Date : 09/08/98

Receipt Date : 09/10/98

Report Date : 10/06/98

\begin{tabular}{|c|c|c|c|c|c|c|c|c|c|c|}
\hline $\begin{array}{l}\text { Client } \\
\text { ID }\end{array}$ & $\begin{array}{c}\text { Quanterra } \\
\text { ID }\end{array}$ & Analyte & CAS Number & $\begin{array}{c}\text { Blank Sample } \\
\text { Name }\end{array}$ & $\begin{array}{l}\text { Prep. } \\
\text { Date }\end{array}$ & $\begin{array}{l}\text { Analyses } \\
\text { Date }\end{array}$ & Result & Unit Qual. & $\begin{array}{l}\text { Detection } \\
\text { Limit }\end{array}$ & Dil. \\
\hline$T-2003-V$ & $18841-001$ & $\mathrm{pH}$. & $c .006$ & QCBLK185289-1 & $09 / 21 / 98$ & $09 / 21 / 98$ & 2.99 & PH UNITS & & 1 \\
\hline I-2003-BKG & $18841-002$ & $\mathrm{pH}$ & c.006. & QCBLK185245-1 & $09 / 16 / 98$ & $09 / 16 / 98$ & 7.39 & PH UNITS & & 1 \\
\hline NA & QCBLK185245-1 & pH & $c-006$ & QCBLK185245-1 & $09 / 16 / 98$ & $09 / 16 / 98$ & 5.72 & PH UNITS & & 1 \\
\hline NA & QCBLK185289-1 & pH & $c-006$ & QCBLK185289-1 & $09 / 21 / 98$ & $09 / 21 / 98$ & 6.20 & PH UNITS & & 1 \\
\hline
\end{tabular}


THIS PAGE IS INTENTIONALLY LEFT BLANK 


\section{APPENDIX C}

\section{WASTE DISPOSAL DOCUMENTS}


THIS PAGE IS INTENTIONALLY LEFT BLANK 
DATE \&-S-98

Reynolds Electrical \& Engineering Co., Inc. Radiological Control Department-Ramatrol

\section{Material Clearance} MONITOR:

ORGANIZATION:

SURVEY LOCATION:

FROM:

TO:<smiles>[R]#CCC</smiles>
$B i t=y$

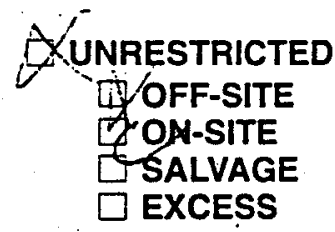

THIS MATERLAL HAS BEEN SURVEYED FOR RADIOACTIVITY AND MEETS DOE STANDARDS FOR REIEASE TO PUBLLC USE"

\section{CONTROLLED}

DESCRIPTION:
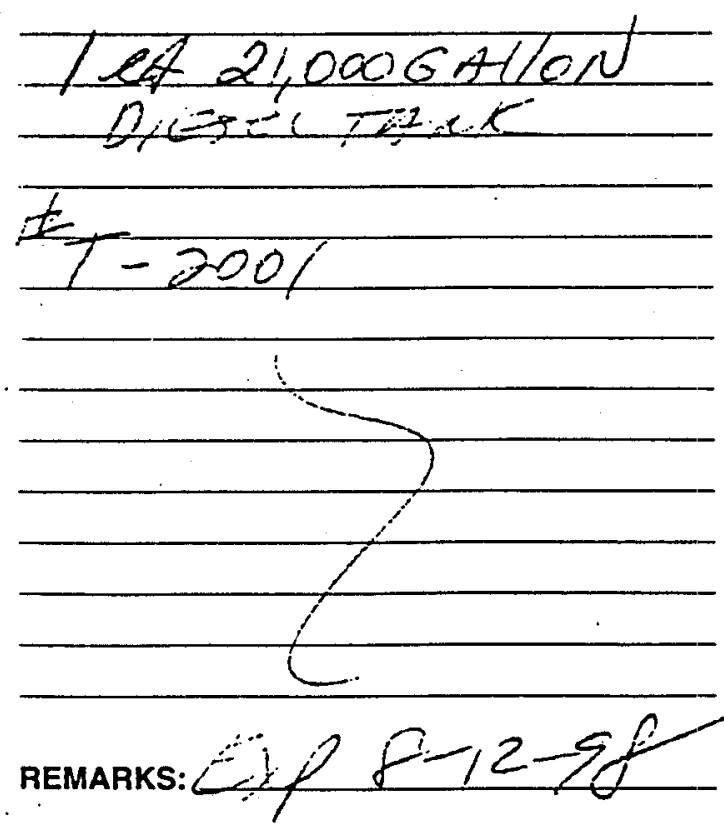
U1OC DISPOSAL SITE

LOAD VERIFICATION DOCUMENT.

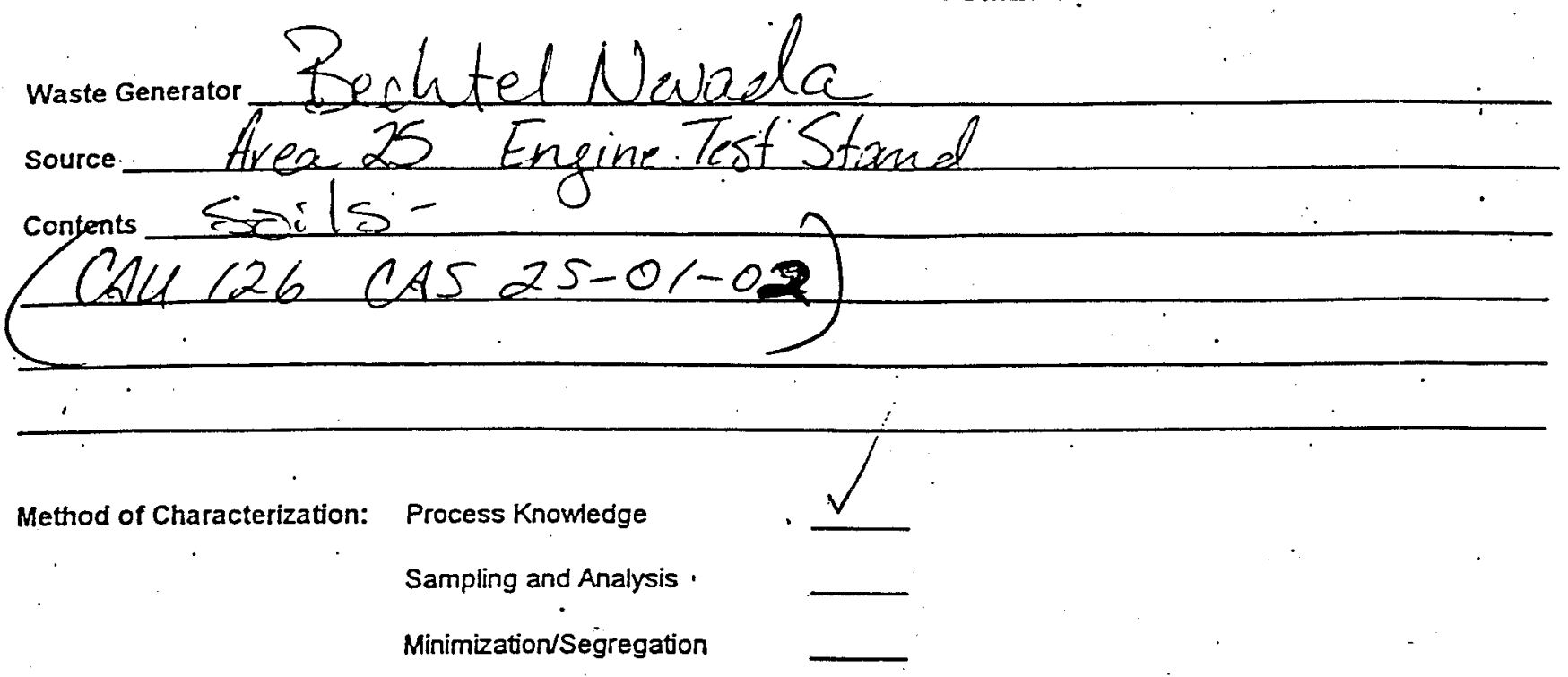

Prohibited Wastes - The following wastes are prohibited from disposal at this site

Radioactive Waste

Sewage sludge
Medical Waste (needles, sharps, bloody clothing)

Friable asbestos
Animal carcasses

PCB (other than light ballasts)
Garbage (food waste)

"Free liquids"

Allowable Wastes - Construction debris containing non-putrescible and highly, Inert waste consistent with the following examples

Asphalt

Rubber

Pipe

Cable and wire

Automobiles and Military Vehicles
Insulation

Plastic

Rocks

Empty containers

210 entice
Metal

Cloth

Non-hydrocarbon burdened soil

Deconned underground and above ground tanks

Wood

Paper

Concrete

Non-friable asbestos

yard hididvocaibon Soil

To the best of my knowledge, the waste described above contains only those materials which are allowed to be disposed of at this disposal site. I have verified this through the waste characterization method Identified above and a review of those prohibited and allowable waste Items.

Print Name

Signature

Date

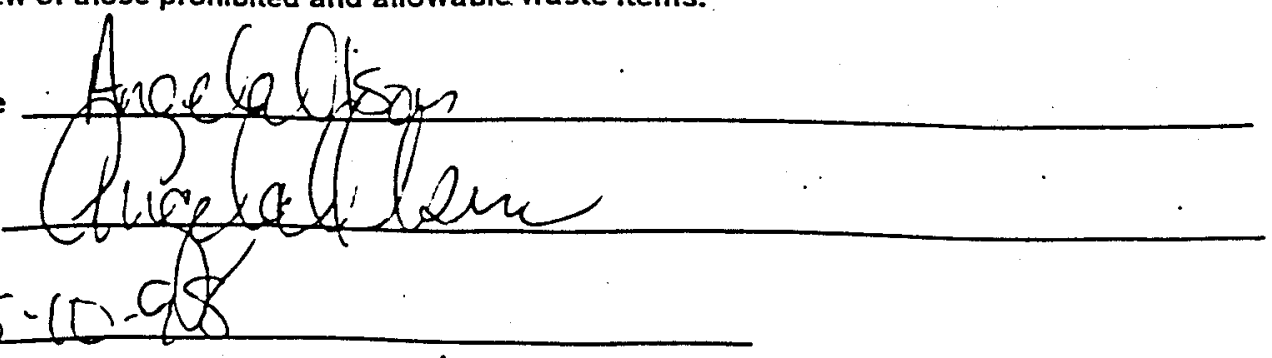

JJMVad__ver.upd 1996 
U10C DISPOSAL SITE

LOAD VERIFICATION DOCUMENT.

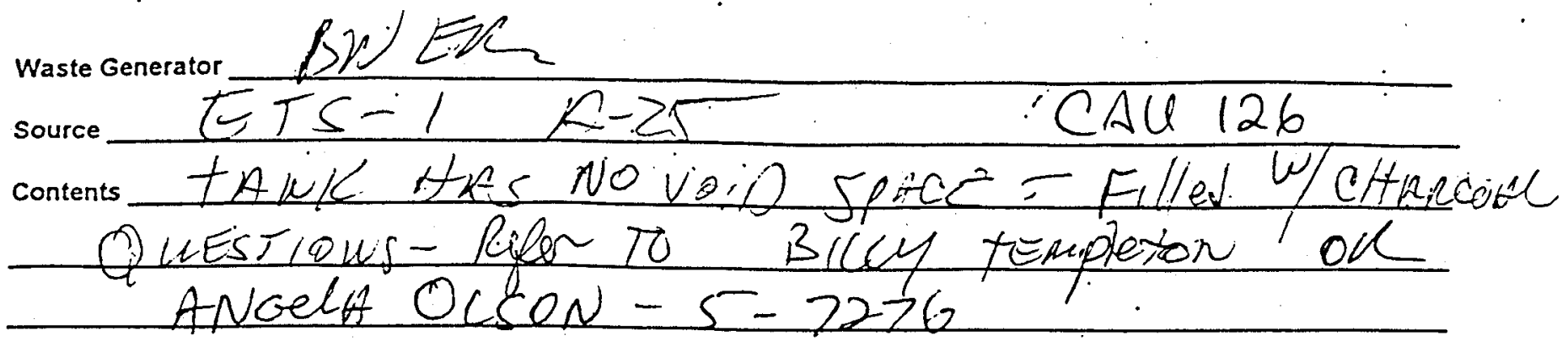

Method of Characterization: Process Knowledge

Sampling and Analysis

Minimization/Segregation

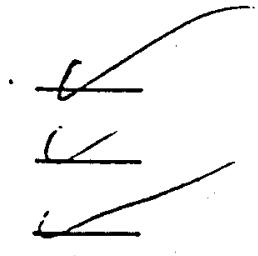

Prohibited Wastes - The following wastes are prohibited from disposal at this site

Radioactive Waste

Sewage sludge
Medical Waste (needles, sharps, bloody clothing)

Friable asbestos
Animal carcasses

PCB (other than light ballasts)
Garbage (food waste)

"Free liquids"

Allowable Wastes - Construction debris containing non-putrescible and highly. inert waste consistent with the following examples

Asphalt

Rubber

Pipe

Cable and wire

Automobiles and Military Vehicles

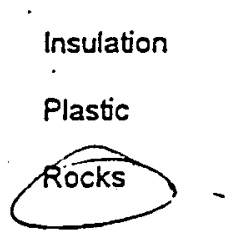

Empty containers

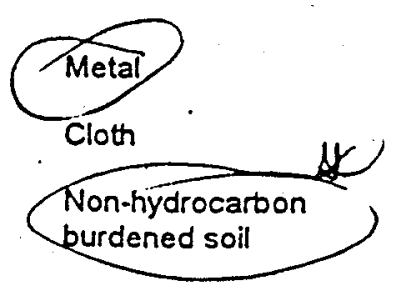

Deconned underground and above ground tanks

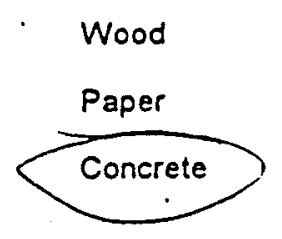

Non-friable asbestos

To the best of my knowledge, the waste described above contains only those materials which are allowed to be disposed of at this disposal site. I have verified this through the waste characterization method identified above and a review of those prohibited and allowable waste items.

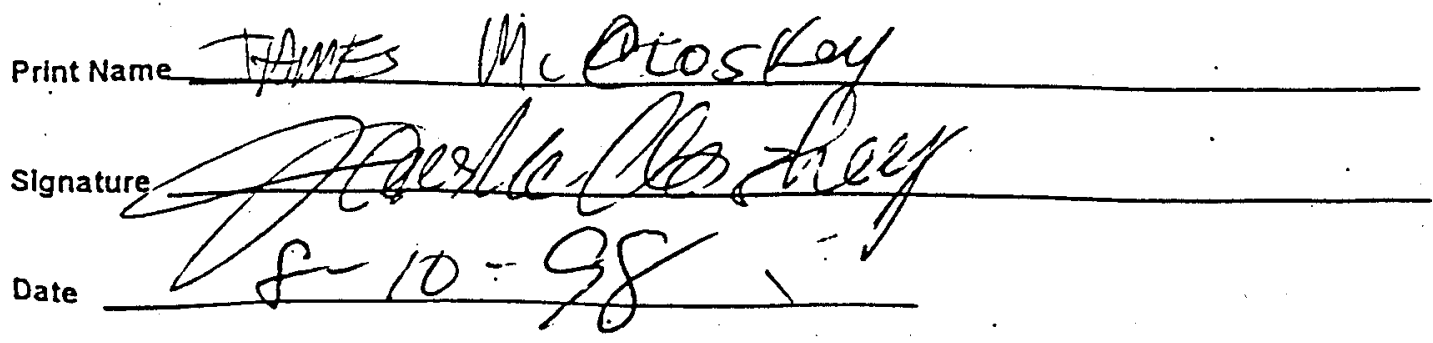

JJMVard_ver wp d $1 / 96$ 
U1OC DISPOSAL SITE

LOAD VERIFICATION DOCUMENT:

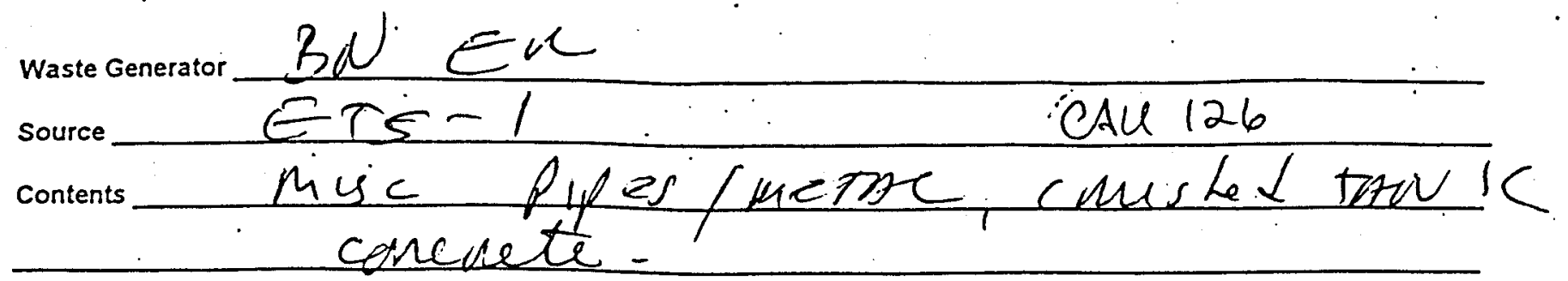

Method of Characterization: Process Knowledge

Sampling and Analysis

Minimization/Segregation

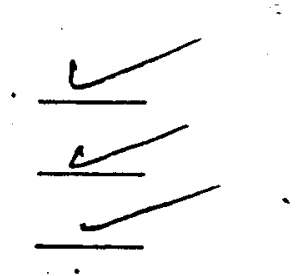

Prohibited Wastes - The following wastes are prohibited from disposal at this site

Radioactive Waste

Medical Waste (needles.

Animal carcasses

Garbage (food waste)

sharps, bloody clothing)

Friable asbestos

PCBs (other than light

"Free liquids"

Sewage sludge ballasts)

Allowable Wastes - Construction debris containing non-putresclble and highly, inert waste consistent with the following examples

Asphalt

Rubber

Pipe

Cable and wire

Automobiles and Military Vehicles $\therefore$ Insulation

Plastic

Rocks

Empty containers

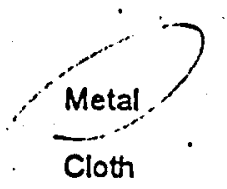

Non-hydrocarbon burdened soil

Deconned underground and above ground tanks

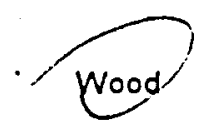

Paper

Concrete

Non-friable asbestos

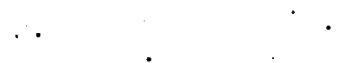

To the best of my knowledge, the waste described above contains only those materials which are allowed to be disposed of at this disposal site. I have verified this through the waste characterization method identified above and a review of those prohibited and allowable waste items.

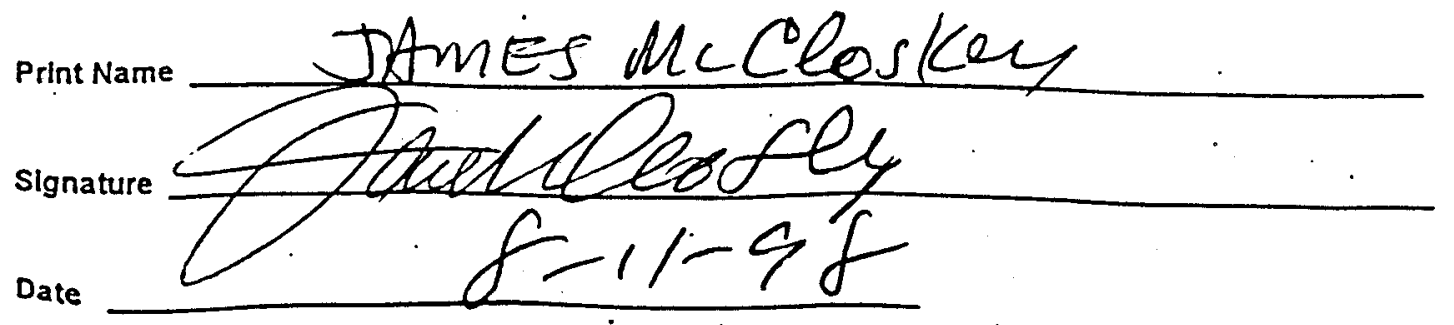

JJMVaad_ver.upd $1 / 96$ 
U10C DISPOSAL SITE

LOAD VERIFICATION DOCUMENT.

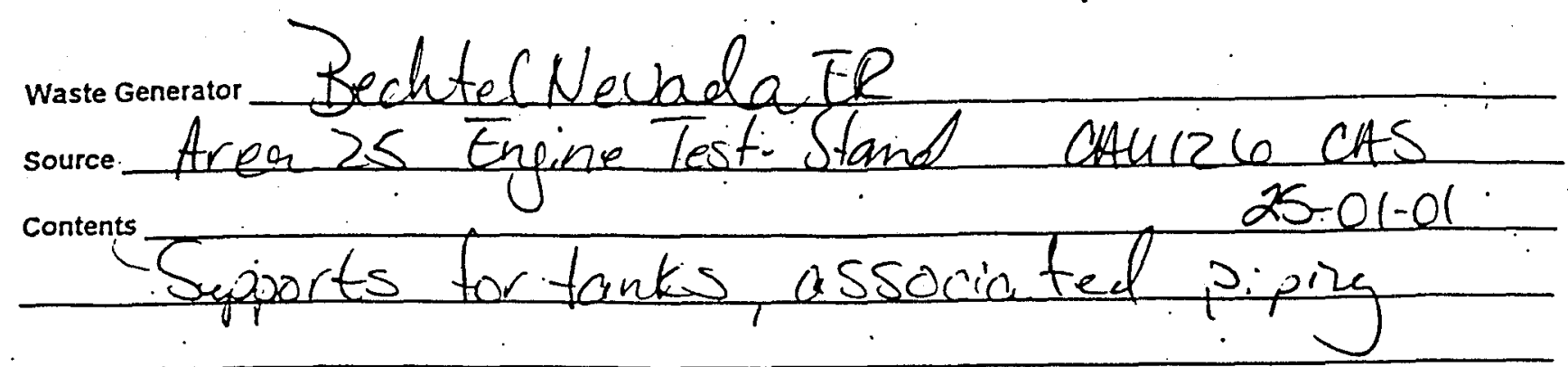

Method of Characterization: Process Knowledge

Sampling and Analysis

MinimizationSSegregation

Prohibited Wastes - The following wastes are prohibited from disposal at this site

Radioactive Waste

Sewage sludge
Medical Waste (needles, sharps, bloody clothing)

Friable asbestos
Animal carcasses

PCB (other than light ballasts)
Garbage (food waste)

"Free liquids"

Allowable Wastes - Construction debris containing non-putrescible and highly, inert waste consistent with the following examples

Asphalt

Rubber

pipe

Cable and wire

Automobiles and Military Vehicles
Insulation

Plastic

Rocks

Empty containers
Metal

Cloth

Non-hydrocarbon burdened soil

Deconned underground and above ground tanks
Wood

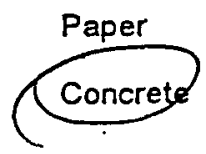

Non-friable asbestos

To the best of my knowledge, the waste described above contains only those materials which are allowed to be disposed of at this disposal site. I have verified this through the waste characterization method identified above and a review of those prohibited and allowable waste items.

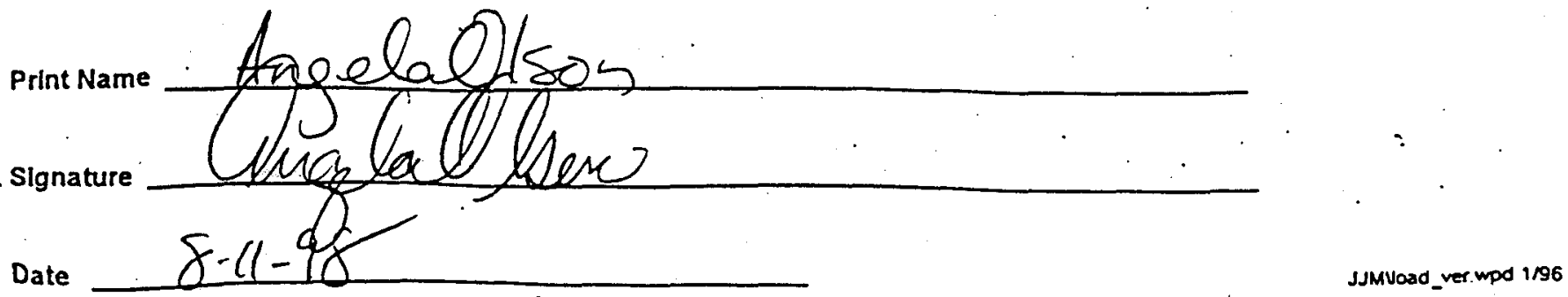


Waste Generator B.N.C.

Source $A-25 \mathrm{CAC} 126$

contents mets! concurete,p,pe

Method of Characterization: Process Knowledge

Sampling and Analysis

Minimization/Segregation

4

Prohibited Wastes - The following wastes are prohibited from disposal at this site

$\begin{array}{llll}\text { Radioactive Waste } & \begin{array}{l}\text { Medical Waste (needles, } \\ \text { sharps, bloody clothing) }\end{array} & \text { Animal carcasses } & \text { Garbage (food waste) } \\ \text { Sewage sludge } & \text { Friable asbestos } & \begin{array}{l}\text { PCBs (other than light } \\ \text { ballasts) }\end{array} & \text { "Free liquids" }\end{array}$

Allowable Wastes - Construction debris containing non-putrescible and hiahlv inert waste consistent with the following examples

Asphat

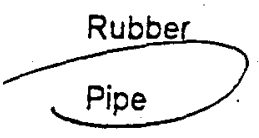

Cable and wire

Automobiles and

Military Vehicles

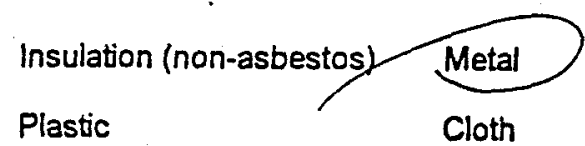

Rocks/Unaltered Geologic Soil Materials

Empty containers
Deconned underground and above ground tanks

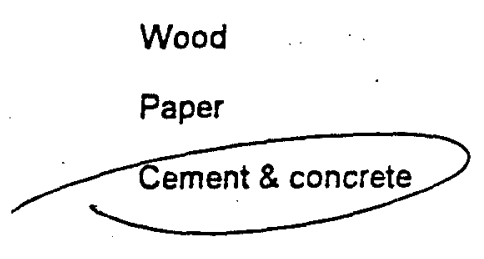

Non-friable asbestos

Hydrocarbon-burdened soil (1 load/day, less than 50 cu. yds./week)

Drained fuel filters (gas \& diesel)

Solid fractions from sandloilwater separators

To the best of my knowledge, the waste described above contains only those materials which are allowed to be disposed of at this disposal site. I have verified this through the waste characterization method identified above and a review of those prohibited and allowable waste items.

Print Name MARQuita Hess

signature 47202 thes?

Date 1248 


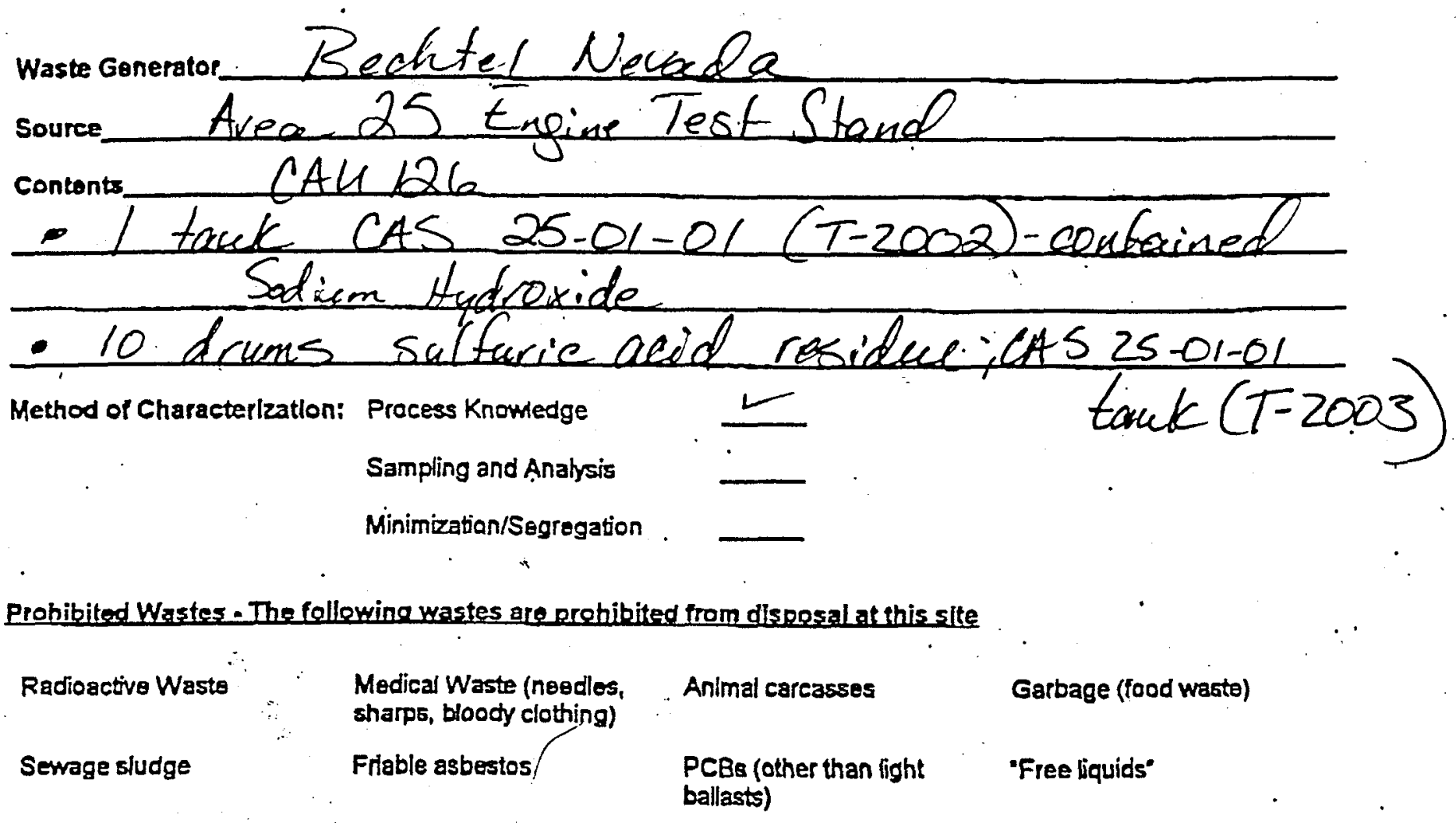

Allowable Wastes - Construction debris centainine non-outrescible and hiahlv. Inert waste consistent with the followingexamoles

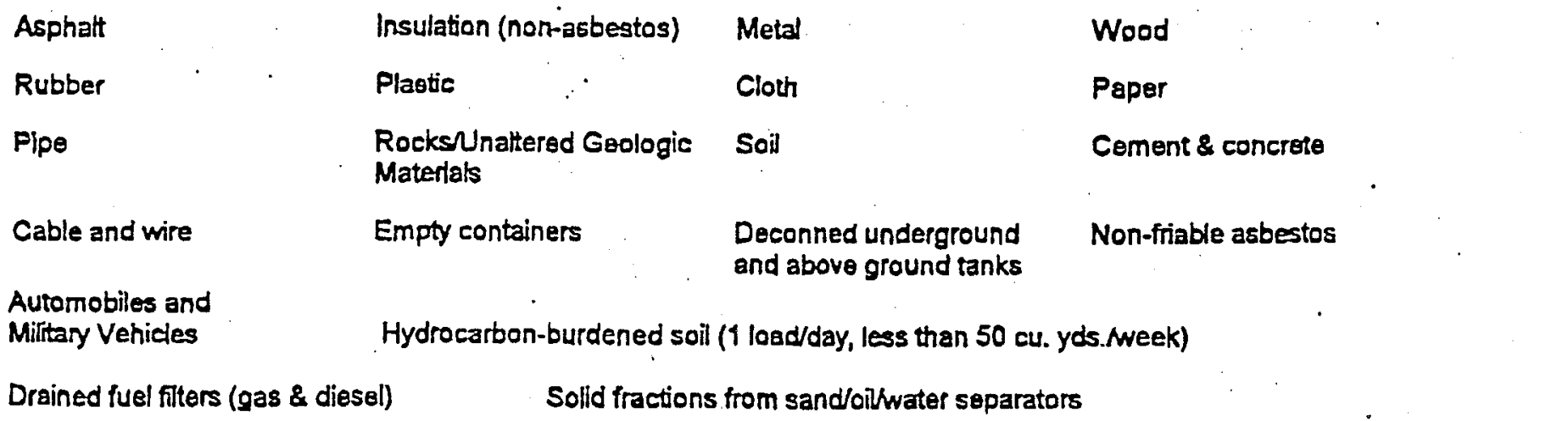

To the best of my knowledge, the waste described abovo contains only those materials which are allowed to be disposed of at this disposal site. I have verfled this through the waste characterization method identified above and a revlew of those prohibited and allowable waste iterns.

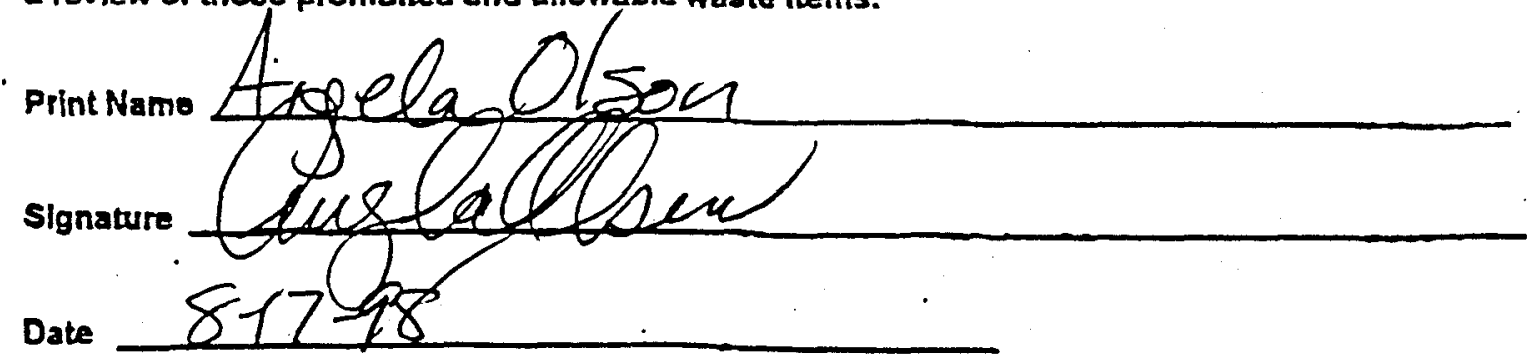




\section{U10C DISPOSAL SITE

Waste Generator SN

Source $A-6$ Sement Sewices

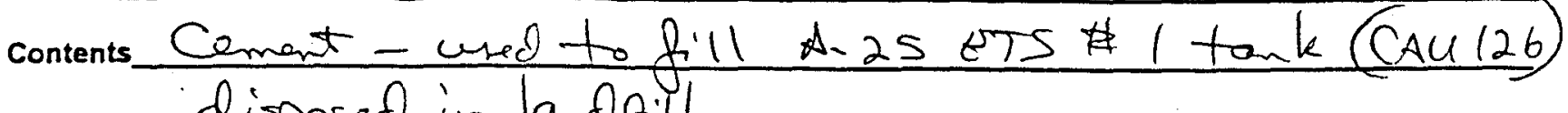
disposed in landpil.

Method of Characterization: Process Knowledge

Sampling and Analysis

Minimization/Segregation

Prohibited Wastes - The following wastes are prohibited from disposal at this site

$\begin{array}{llll}\text { Radioactive Waste } & \begin{array}{l}\text { Medical Waste (needles, } \\ \text { sharps, bloody clothing) }\end{array} & \text { Animal carcasses } & \text { Garbage (food waste) } \\ \text { Sewage sludge } & \text { Friable asbestos } & \begin{array}{l}\text { PCBs (other than light } \\ \text { ballasts) }\end{array} & \text { "Free liquids" }\end{array}$

Allowable Wastes - Construction debris centainina non-putrescible and hiably inert waste consistent with the following examples

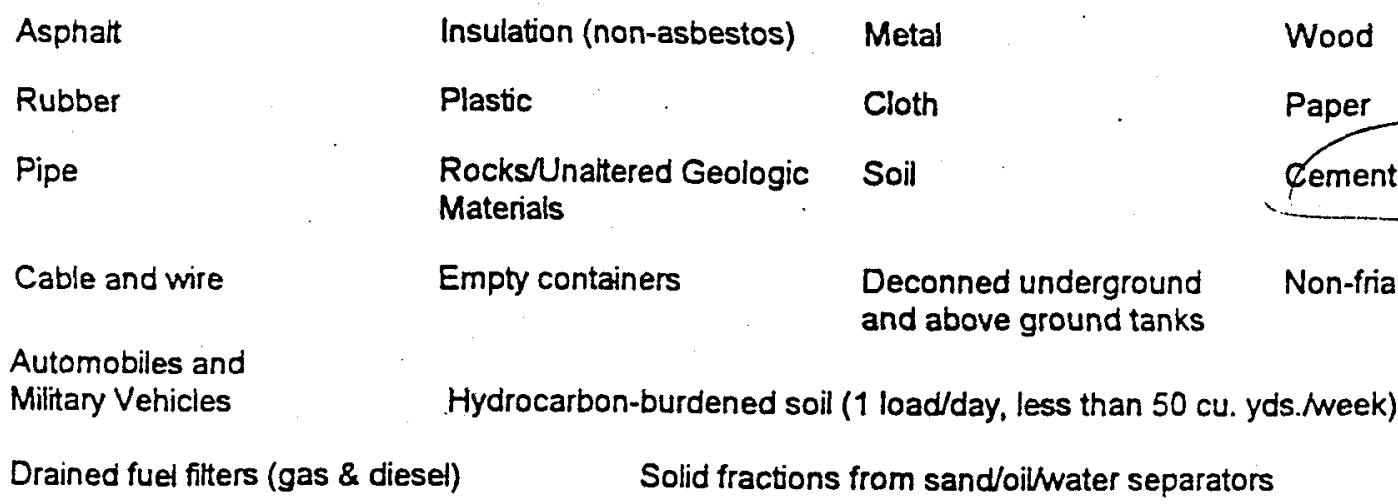

To the best of my knowledge, the waste described above contains only those materials which are allowed to be disposed of at this disposal site. I have verified this through the waste characterization method identified above and a review of those prohibited and allowable waste items.

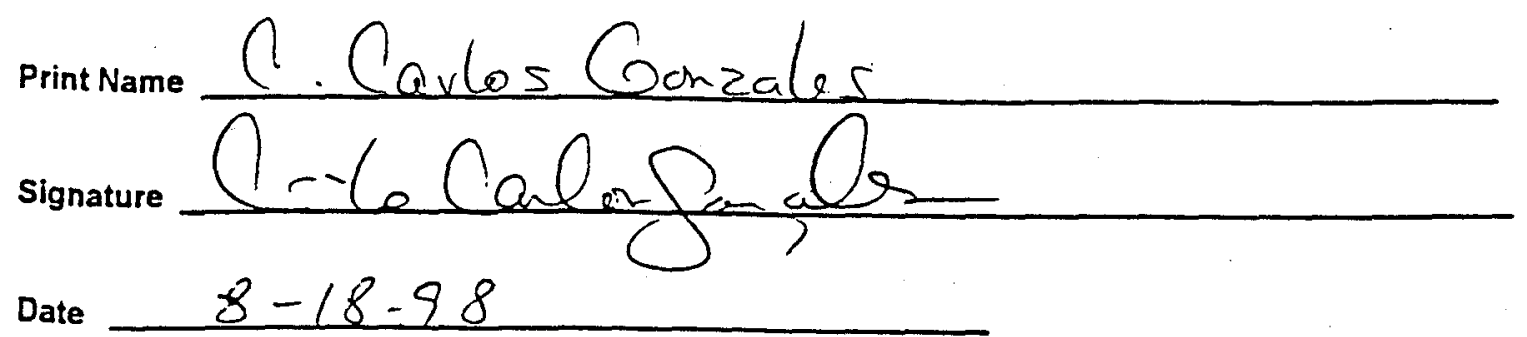


Waste Generator $B N$

source $D>22$ Oement Senticer

contents Cement - jilling ETS \#1 tonk disposedion lonofill.

Method of Characterization: Process Knowledge

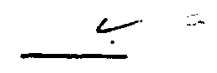

Sampling and Analysis

Minimization/Segregation

Pronibited Wastes - The following wastes are prohibited from disposal at this site

$\begin{array}{llll}\text { Radioactive Wasie } & \begin{array}{l}\text { Medical Waste (needles, } \\ \text { sharps, bloody clothing). }\end{array} & \text { Animal carcasses } \\ \text { Sewage siudge } & \text { Friable asbestos }: & \begin{array}{l}\text { PCBs (other than light } \\ \text { ballasts) }\end{array} & \text { "Free liquids" }\end{array}$

Allowaple Wastes - Construction debris containing non-putrescible and hiahlv. inert waste consistent with the foiloivini axampies

\begin{tabular}{|c|c|c|c|}
\hline Asp̣näit & Insulation (non-asbestos) & Metal & Wood \\
\hline Rucber & Plasic & Cloth & Paper \\
\hline Pine & $\begin{array}{l}\text { Rocks/Unaltered Geologic } \\
\text { Materials }\end{array}$ & Soil & \\
\hline Cade anc :.rre. & Empy containers & $\begin{array}{l}\text { Deconned underground } \\
\text { and above ground tanks }\end{array}$ & Non-fria \\
\hline Auicmadies and & \multirow{2}{*}{\multicolumn{3}{|c|}{ Hydrocarbon-burdened soil ( 9 load/day, less than $50 \mathrm{cu} . y \mathrm{ds}$./week) }} \\
\hline Miltary l'encicies & & & \\
\hline
\end{tabular}

To the sest of my knowiedge. the waste described above contains only those materials which are allowed to be dis posed ci at this cisposal site. I have verified this through the waste characterization method identified above and a review or those prohibited and allowable waste items.

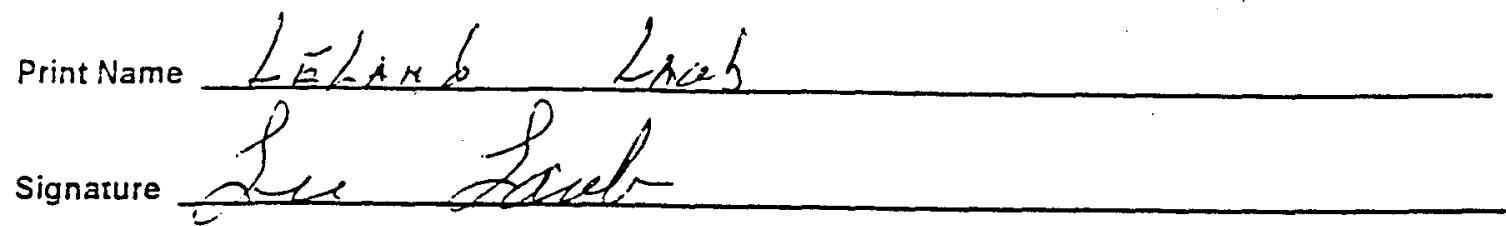

Date

$8-19-98$ 


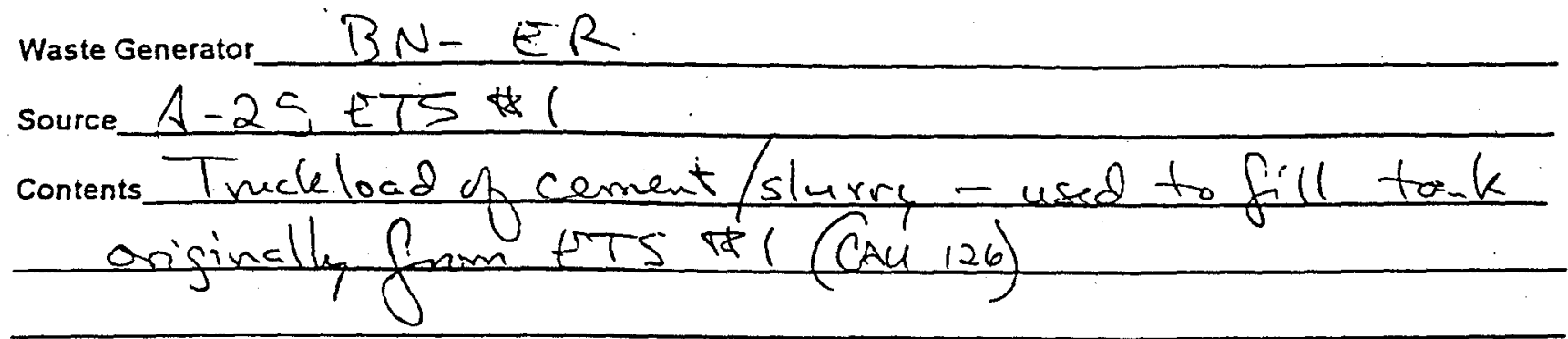

Method of Characterization: Process Knowledge

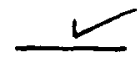

Sampling and Analysis

Minimization/Segregation

Prohibited ! Vastes - The following wastes are prohibited from disposal at this site
Racioacaive Waste
Medical Waste (needles, sharps, bloody clothing)
Animal carcasses
Garbage (food waste)
Sewage siudge
Friable asbestos
PCBs (other than light ballasts)
"Free liquids"

Alloviacle $\mathrm{V} / \mathrm{astes}$ - Construction debris containing non-putrescible and highiv, inert waste consistent with the foilo:vina examoies

$\begin{array}{llll}\text { Asprant } & \text { Insulation (non-asbestos) } & \text { Metal } & \text { Wood } \\ \text { Rusier } & \text { Plastic } & \text { Cloth } & \text { Paper } \\ \text { Pice } & \begin{array}{l}\text { Rocks/Unaltered Geologic } \\ \text { Materials }\end{array} & \text { Soil } & \text { Cement \& concrete } \\ \text { Cad: Enc:ire } & \text { Empty containers } & \begin{array}{l}\text { Deconned underground } \\ \text { and above ground tanks }\end{array} & \text { Non-friable asbestos }\end{array}$

Automos:ies and

Militany 'énicies

Hydrocarbon-burdened soil ( 1 load/day, less than $50 \mathrm{cu}$. yds./week)

Drained icel fitters (gas \& diesel)

Solid fractions from sand/oilwater separators

To the sest of my knowiedge, the waste described above contains only those materials which are allowed to be disposed of at this disposal site. I have verified this through the waste characterization method identified above and a review of those prohibited and allowable waste items.

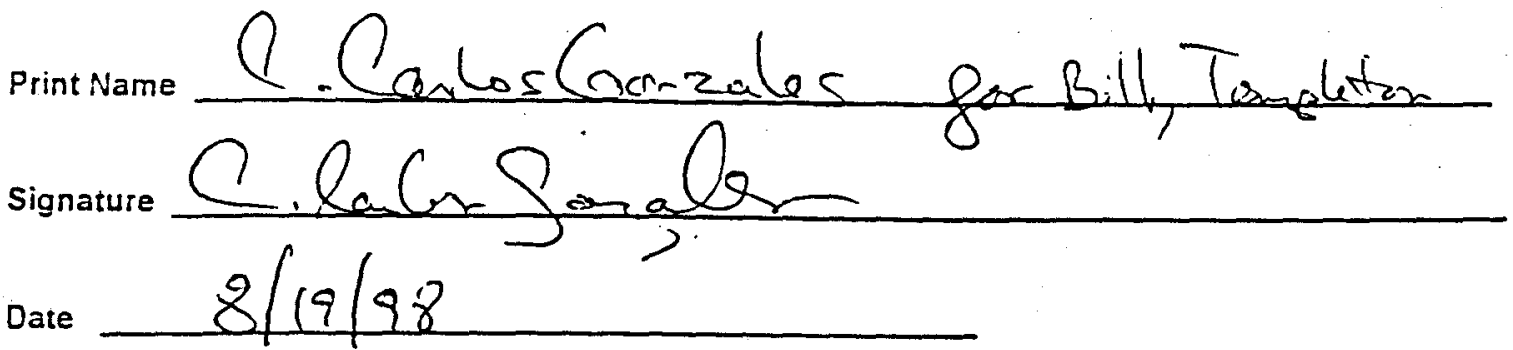


THIS PAGE IS INTENTIONALLY LEFT BLANK 


\section{DISTRIBUTION LIST}


THIS PAGE IS INTENTIONALLY LEFT BLANK 


\section{DISTRIBUTION LIST}

Copies

Paul Liebendorfer

Bureau of Federal Facilities

Division of Environmental Protection

333 W. Nye Lane, Room 13B

Carson City, NV 89706-0866

Micheal D. McKinnon

Bureau of Federal Facilities

Division of Environmental Protection

555 E. Washington, Suite 4300

Las Vegas, NV 89101

U. S. Department of Energy, Nevada Operations Office

Environmental Restoration Division

P. O. Box 98518

Las Vegas, NV 89193-8518

J.L. Appenzeller-Wing

C. W. Barrow

S. Lawrence

U.S. Department of Energy

Nevada Operations Office

Public Reading Facility

P.O. Box 98521, M/S NLV040

Las Vegas, NV 89193-8521

U.S. Department of Energy

Nevada Operations Office

Technical Information Resource Center

P.O. Box $98518, \mathrm{M} / \mathrm{S} 505$

Las Vegas, NV 89193-8518 
U. S. Department of Energy,

Office of Scientific and Technical Information

175 Oak Ridge Turnpike

P. O. Box 62

Oak Ridge, TN 37831-0062

Bechtel Nevada

P. O. Box 98521

Las Vegas, NV 89193-8521

Correspondence Control

EM Correspondence Control

A. L. Olson

D. K. Cowser

S. J. Nacht

A. M. Heidema 


\section{DOCUMENT REVIEW FORM}

1. Document Title/number: Streamlined Approach for Environmental Restoration Closure Report for Corrective Action Unit 126 Area 25 Aboveground Storage Tanks, Nevada Test Site, Nevada, DOE/NV/11718--260

2. Document Date: November 12, 1998

3. Revision Number: 0

4. Originator/Organization: Angela Olson, Task Manager, Bechtel Nevada Environmental Restoration, 295-7276

5. Responsible DOE/NV ERP Task Manager: Clayton Barrow

6. Review Criteria: Full

7. Reviewer/Organization: Michael McKinnon, Nevada Division of Environmental Protection

\begin{tabular}{|c|c|c|c|c|}
\hline $\begin{array}{l}\text { 1. Page } 10, \\
\text { Section } \\
2.1 .2\end{array}$ & M & $\begin{array}{l}\text { To be consistent, the T- } 2001 \\
\text { identifier should immediately follow } \\
\text { the above description of this section. }\end{array}$ & Identifier added. & $Y$ \\
\hline $\begin{array}{l}\text { 2. Page } 11 \\
\text { Section } \\
2.1 .3\end{array}$ & M & $\begin{array}{l}\text { To be consistent, the T- } 2401 \\
\text { identifier should immediately follow } \\
\text { the above description of this section. }\end{array}$ & Identifier added. & $\mathrm{Y}$ \\
\hline $\begin{array}{l}\text { 3. Page } 11 \\
\text { Section } \\
2.1 .4\end{array}$ & M & $\begin{array}{l}\text { To be consistent, the D- } 2001 \\
\text { identifier should immediately follow } \\
\text { the above description of this section. }\end{array}$ & Identifier added. & $Y$ \\
\hline
\end{tabular}




\begin{tabular}{|c|c|c|c|c|}
\hline $\begin{array}{l}\text { 4. Page } 20 \\
\text { Section } 3.4\end{array}$ & $\mathrm{M}$ & $\begin{array}{l}\text { The disposition of personal } \\
\text { protective equipment (PPE) should } \\
\text { be mentioned in this section. }\end{array}$ & Text modified as requested. & $\mathrm{Y}$ \\
\hline $\begin{array}{l}\text { 5. Page } 21 \\
\text { Section } 4.1\end{array}$ & M & $\begin{array}{l}\text { Whether further action is required at } \\
\text { this site is dependent upon the } \\
\text { results of the samples; therefore, this } \\
\text { statement is premature. }\end{array}$ & $\begin{array}{l}\text { Sample results were received. Text } \\
\text { was modified to show that further } \\
\text { action is required. }\end{array}$ & $\mathrm{Y}$ \\
\hline $\begin{array}{l}\text { 6. Page } 21 \\
\text { Section } 4.2\end{array}$ & $\mathrm{M}$ & $\begin{array}{l}\text { This section is in direct } \\
\text { contradiction to Section } 2.1 .2 \\
\text { wherein a discharge from a drain } \\
\text { valve is documented. Also, in the } \\
\text { Final SAFER Work Plan for CAU } \\
\text { 126, Revision 1, July 1998, Page } 3 \text {, } \\
\text { last sentence, the text indicates } \\
\text { "...removing the associated } \\
\text { piping...from all the sites..." There } \\
\text { is no indication that the piping } \\
\text { associated with this tank has been } \\
\text { removed. }\end{array}$ & $\begin{array}{l}\text { In each section, the text was } \\
\text { modified to include what was done } \\
\text { with the associated piping specific } \\
\text { to each tank. This issue is also } \\
\text { clarified in the Deviations to the } \\
\text { Work Plan section of the document. }\end{array}$ & $Y$ \\
\hline
\end{tabular}




\begin{tabular}{||c|c|c|c|c||}
\hline $\begin{array}{c}\text { 8. } \\
\text { Comment } \\
\text { Number/ } \\
\text { Location }\end{array}$ & 9.Type & 10. Comment & 11. Comment Response \\
\hline \hline $\begin{array}{l}\text { 7. Page 23, } \\
\text { Section 5.1, } \\
\text { 3rd bullet }\end{array}$ & $\mathrm{M}$ & $\begin{array}{l}\text { “...disconnecting the piping..." As } \\
\text { mentioned in the previous } \\
\text { paragraph, the SAFER Work Plan } \\
\text { specified removal of all associated } \\
\text { piping. }\end{array}$ & $\begin{array}{l}\text { The text was modified to clarify } \\
\text { this issue in the Deviations to the } \\
\text { Work Plan section of the document. }\end{array}$ \\
\hline
\end{tabular}

Notes: ${ }^{a}$ Comment Types: $M=$ Mandatory, $S=$ Suggested 